\title{
A GENERAL INVESTMENT AGREEMENT IN THE WTO? LESSONS FROM CHAPTER 11 OF NAFTA AND THE OECD MULTILATERAL AGREEMENT ON INVESTMENT
}

\author{
JÜRGEN KURTZ*
}

\section{INTRODUCTION}

Unlike the system of trade liberalization in the World Trade Organization ("WTO"), there has never been a comprehensive, multilateral agreement on foreign investment. Binding international initiatives on foreign investment exist largely at the bilateral, ${ }^{2}$ regional, ${ }^{3}$ and sectoral ${ }^{4}$ levels. This is true despite exponential growth in rates of foreign investment and the increasing complementariness of trade and investment as strategies for penetrating domestic markets.

At the Fourth WTO Ministerial Conference at Doha in Qatar, an agreement appears to have been reached to commence investment negotiations at the Fifth Ministerial Conference in Mexico in

* Emile Noël Fellow, Jean Monnet Center for International and Regional Economic Law \& Justice, New York University Law School; Lecturer, Law School, The University of Melbourne, Australia. This Article was written during an Emile Noël fellowship at NYU Law School. I thank Professor J.H.H. Weiler of NYU Law School for that rewarding opportunity, his valuable comments, and support for this work. All errors remain, of course, my own

1 Marrakesh Agreement Establishing the World Trade Organization, Final Act Embodying the Results of the Uruguay Round of Multilateral Trade Negotiations, Apr. 15, 1994, vol. 33, 33 I.L.M. 1144 (1994).

2 See generally RUDOLF DOLZER \& MARGRETE STEVENS, BILATERAL INVESTMENT TREATIES (1995) [hereinafter DOLZER \& STEVENS] (featuring a comprehensive discussion of the use and coverage of bilateral investment treaties).

3 See, e.g., North American Free Trade Agreement, Dec. 17, 1992, chs. 1-22, 32 I.L.M. 289, 289-605 (1993) [hereinafter NAFTA] (providing the text of treaty establishing a free trade zone in North America). The member states of NAFTA are the United States, Canada, and Mexico. The investment provisions are found in Chapter 11 of the NAFTA.

4 See, e.g., Energy Charter Treaty, Dec. 17, 1994, Part III, 33 I.L.M. 381 (1995) (providing for the liberalization of investment restrictions and investment protection amongst a large number of Organisation for Economic Co-operation and Development (OECD) and Eastern European states within the energy sector). 
2003. ${ }^{5}$ However, it was only in 1998 that similar negotiations in the Organisation for Economic Co-operation and Development ("OECD") towards a Multilateral Agreement on Investment ("MAI") ended without result. The MAI provisions themselves were heavily influenced by the detailed investment provisions in Chapter 11 of the North American Free Trade Agreement ("NAFTA"). This Article will examine both of these instruments and attempt to draw some suggestions for future investment negotiations within the WTO. The Article will argue that there are essentially two challenges that negotiators face in creating investment rules in the WTO.

Primarily, a WTO agreement must reflect the interests of developing countries. Historically, developing countries (largely serving as host countries for foreign investment) have resisted initiatives to develop investment rules at the multilateral level. Indeed, the choice of the OECD (composed mainly of developed states) as the negotiating forum for the MAI was driven by a desire to exclude developing countries from negotiations due to the concern that the developing states' demands would dilute the MAI commitments. However, the options for negotiation should not be viewed in absolutist terms as either full liberalization of discriminatory regulation or full protectionism. A more subtle approach is warranted. In part, the solution lays in understanding the different rationales and methods by which states regulate foreign investment. This Article will undertake such an analysis so as to suggest realistic ways in which to craft a WTO investment agreement broadly reflective of the interests of the members of the WTO from the North and South.

There is also a second formidable, albeit less obvious, challenge. The NAFTA Chapter 11 model (and that of the MAI) provides for a trinity of strong investment liberalization, investment protection, and dispute settlement provisions. In recent years, there has been a proliferation of arbitral cases brought by investors under NAFTA Chapter 11. The jurisprudence that has emerged from some of these cases extends the coverage of NAFTA Chapter 11 beyond clearly discriminatory measures to seemingly legitimate regulations with little adverse impact on foreign investors. This raises the difficult issue of drafting a WTO investment agreement

5 WTO, Ministerial Declaration: Ministerial Conference Fourth Session Doha, WT/MIN(01)/DEC/1 20 (Nov. 14, 2001), ๆl 20-22 [hereinafter Doha Ministerial Declaration]. 
in such a way as to preserve core components of regulatory autonomy. The Article will argue that WTO negotiators should not simply look to the NAFTA precedent as the only model available. Instead, the Article will suggest ways in which negotiators can define commitments in a WTO initiative to avoid some of the problems that have arisen under NAFTA Chapter 11.

This Article is organized as follows. Section 2 offers some background material. It examines statistical evidence showing that developing countries are largely host states for foreign investment. It also details the shifting policy attitudes of host states towards foreign investment and the way in which those changes have influenced the content of existing international rules on investment. Section 3 then outlines the way in which states typically regulate foreign investment driven by a complex mix of political and economic motives. The analysis focuses on the common (but distortive) practice of using incentives to attract foreign investors. Section 4 examines the NAFTA Chapter 11 model and the jurisprudence that has emerged from some of the NAFTA arbitral cases. Section 5 examines the MAI, its heavy reliance on the NAFTA model, and belated attempts to rectify some of the problems inherent in that model. Section 6 considers the Doha negotiating agenda and prospects for concluding negotiations with a viable investment agreement in the WTO. Section 6 ties together different lines of inquiry and puts forward a series of suggestions on the two major challenges facing WTO negotiators. Section 7 concludes the Article.

\section{BACKGROUND}

\subsection{Foreign Investment in the Global Economy}

The last few decades have witnessed exponential growth in foreign investment, particularly in foreign direct investment ("FDI"). FDI is normally defined as ownership with some form of control of all or part of a business in another country. ${ }^{6}$ The key determinant is that the foreign investor has a degree of managerial

6 See InTERnational MONETARy Fund, Balance of Payments Manual If 408 (4th ed. 1977) [hereinafter IMF] ("FDI] is made to acquire a lasting interest in an enterprise operating in an economy other than that of an investor, the investor's purpose being to have an effective choice in the management of the enterprise."). 
control over the business. ${ }^{7}$ The relatively long-term nature of FDI is often distinguished from portfolio investment where a foreign investor purchases securities or debt instruments without the desire to control or manage the domestic firm. ${ }^{8}$

Global FDI inflows rose from U.S. $\$ 202$ billion in 1990 to U.S. $\$ 1.27$ trillion in 2000.9 Most FDI originates from and is destined for developed countries. In fact, within the developed world, the socalled "Triad" consisting of the European Union ("EU"), the United States and Japan, accounted for seventy-one percent of global FDI inflows in 2000.10 These countries also account for most of the world's outflows of FDI with eighty-two percent of global outflows coming from the Triad countries in 2000.11 This concentration is also evidenced by the fact that about ninety of the world's largest 100 non-financial transnational corporations (a primary mechanism for delivering FDI) are headquartered in the Triad countries. 12

In comparison, developing countries accounted for only nineteen percent of global FDI inflows in 2000.13 This represents a decline since 1994, when the share of those countries accounted for

7 However, there are differences in the approaches taken by various international economic organizations in setting the quantum of managerial control in order for an investment to qualify as FDI. See ORGANISATION FOR ECONOMIC COOPERATION AND DEVElOPMENT, BENCHMARK DEFINITION OF FOREIGN DIRECT INVESTMENT ף 8 (3d ed. 1996) [hereinafter OECD]

The numerical guideline of ownership of ten percent of ordinary shares or voting stock determines the existence of a direct investment relationship. An effective voice in the management, as evidenced by an ownership of at least ten percent, implies that the direct investor is able to influence or participate in the management of an enterprise; it does not require absolute control by the foreign investor.

Id. But cf. IMF, supra note 6, \$1 411-3 (finding that the required quantum of control may vary depending on whether ownership in the enterprise is concentrated or diffused).

8 IMF, supra note 6, If 409 ("In contrast, portfolio investors are primarily concerned about the safety of their capital, the likelihood of an appreciation in its value, and the return that it is bringing them. They will evaluate the prospects separately. .. and may often shift their capital with changes in these prospects.").

9 UNITED NATIONS CONFERENCE ON TRADE AND DEVElopMENT (UNCTAD), WORLD INVESTMENT REPORT 2001: PROMOTING LINKAGES 10 (2001) [hereinafter WORLD INVESTMENT REPORT 2001].

$10 \mathrm{Id}$. at 9.

11 Id.

12 Id. at $\mathrm{xv}$.

13 Id. at 9. 
forty-one percent of global FDI inflows. ${ }^{14}$ Also, flows of FDI are heavily concentrated within particular parts of the developing world. Of the U.S. \$240 billion of FDI flows into the developing world in 2000, U.S. $\$ 64$ billion went to Hong Kong (China) and U.S. $\$ 41$ billion to China. ${ }^{15}$ In comparison, Africa remained severely marginalized as a host continent for FDI with its share in total inflows falling below one percent. ${ }^{16}$ Developing countries also remain largely capital importers or host states for FDI. They only accounted for approximately eight percent of FDI outflows in 1999.17

From the perspective of a possible WTO investment agreement, there is also a close relationship between foreign investment and trade. Intra-firm trade among transnational corporations ("TNCs") accounts for approximately one-third of world trade while TNC exports to non-affiliated entities account for another one-third of world trade. ${ }^{18}$ There is increased recognition that trade and FDI are two ways of servicing foreign markets. They are sometimes employed alternatively, but increasingly, they are used as complementary modes of servicing foreign markets. This trend is probably best recognized in the WTO General Agreement on Trade in Services ("GATS"), which includes the concept of "commercial presence" in the definition of trade in services (recognizing that FDI is a prerequisite for exporting many services). ${ }^{19}$

Despite the growth in FDI and its linkage to trade, developing countries (as net capital importers or host states for FDI) are not naturally demandeurs of multilateral investment rules. In fact, during the General Agreement on Tariffs and Trade ("GATT") Uruguay Round negotiations from 1986 to 1994, a number of developing countries opposed a U.S. proposal to include a comprehensive investment agreement on the negotiating agenda. Consequently, the United States reacted by advocating investment negotiations under the aegis of the OECD in the early 1990s. While the tension

14 Id.

15 Id. at xiii-xiv.

16 Id.

17 UNCTAD, WORLD INVESTMENT REPORT 2000: CROSS-BORDER MERGERS AND ACQUISITIONS AND DEVELOPMENT 20, fig. 1.9 (2000) [hereinafter WORLD INVESTMENT REPORT 2000].

18 WTO, ANNUAL REPORT 199644 (1996).

19 General Agreement on Trade in Services, Apr. 15, 1994, Final Act Embodying the Results of the Uruguay Round of Multilateral Trade Negotiations Annex 1B, LEGAL INSTRUMENTS-RESULTS OF THE URUGUAY ROUND vol. 33, 33 I.L.M. 1167 (1994) [hereinafter GATS]. 
between North and South has characterized much of the history of international rulemaking on foreign investment, the policy perspectives between North and South have remained neither absolute nor static. The next Section will examine the shifting policy pendulum on foreign investment and the way in which it has influenced the content of the existing international framework on foreign investment.

\subsection{International Investment Rules: A Fragmented Landscape}

In recent years, investment has often been debated as one of the new issues for a future WTO negotiating agenda. However, the first attempt to create multilateral treaty-based rules on foreign investment can be traced back to the immediate post-Second World War period. In 1948, the Charter for an International Trade Organization ("ITO") was presented to a meeting of fifty-six states in Havana. ${ }^{20}$ The ITO was to have been the third pillar of post-war economic cooperation together with the International Monetary Fund and the World Bank.21

Despite the opposition of developing countries, the U.S. delegation eventually succeeded in including provisions within the ITO Charter dealing with foreign investment.22 However, the rights

20 For excerpts from the Havana Charter, see UNCTAD, INTERNATIONAL INVESTMENT INSTRUMENTS: A COMPENDIUM 3 (1996) [hereinafter INTERNATIONAL INVESTMENT INSTRUMENTS] (detailing the attempted creation of an international framework).

21 It is instructive to note that, whilst many of the Havana Charter provisions dealt with trade liberalization (Chapter IV), there were also provisions on employment (Chapter II), development (Chapter III), restrictive business practices (Chapter V), and agriculture (Chapter VI). This reflected a conception of the ITO as a regime to advance economic liberalization but within a broader regulatory context. The regulatory dimension of the ITO appears to be linked to the concept of the regulatory state embodied in President Roosevelt's New Deal. With the eventual demise of the ITO, the role of regulation has come to be primarily viewed more as a domestic rather than a multilateral concern. See generally AnnMarie Burley, Regulating the World: Multilateralism, International Law, and the Projection of the New Deal Regulatory State, in MULTILATERALISM MATTERS: THE THEORY AND PRAXIS OF AN INSTITUTIONAL FORM 125 (John Ruggie ed., 1993) (discussing the New Deal's influence in an international context).

22 For an overview of the negotiations leading towards the Havana Charter, see Claire Wilcox, A CHARTER FOR WORLD TRADE 37-50 (1949) (discussing the preparations, issues, and significance of Havana). See also Daniel M. Price \& P. Bryan Christy, III, Agreement on Trade Related Investment Measures (TRIMS): Limitations and Prospects for the Future, in THE WORLD TRADE ORGANIZATION: THE MULTILATERAL FRAMEWORK FOR THE 21ST CENTURY AND U.S. IMPLEMENTING LeGislation 439, 443-45 (Terence P. Stewart ed., 1996) (discussing how "the inter- 
eventually granted to foreign investors in the Charter were substantially diluted from earlier articles put forward by the United States. ${ }^{23}$ From the perspective of the American business community, the overall structure of the Charter appeared to favor host over home countries. There was particular objection by the American business community to the Charter provisions regulating anticompetitive behavior by private enterprises. 24 These objections were a major reason for the eventual failure of the U.S. Senate to ratify the Charter. As the United States accounted for roughly half of world trade at that time, the ITO became, in effect, stillborn, and the entire ITO project was subsequently abandoned.

In the aftermath of the defeat of the Charter, GATT (a temporary measure of the ITO) was the only body left standing. The GATT was drawn up and signed as an interim tariff reduction agreement in 1947, intended to operate until the ITO was formally established. The GATT made no attempt to deal with foreign investment issues. This institutional separation of trade from investment issues in the multilateral arena continued until the Uruguay Round in the 1980s. Indeed, the failure of the ITO marked a shift away from multilateralism in the coverage of investment instruments. By the late 1960s, bilateral investment treaties ("BITs") had become the primary instruments for reaching agreement on

ests of developing countries ... dominated [Havana] Charter provisions on investments").

23 The early articles proposed by the U.S. delegation at a meeting in Geneva in 1947 set out extensive rights for investors including the obligation of host states to accord national treatment as well as unqualified most-favored-nation treatment. These extensive rights provoked opposition by a number of countries, including the Czech government, which refused to give German investors the same status as other foreign investors. This is a very early illustration of the point (which will be raised later in this Article) that national regulation of foreign investment is often motivated by overtly sovereignty-related concerns. The resulting compromise is reflected in Article 12 of the ITO Charter, which significantly dilutes the liberalization commitments proposed by the U.S. delegation. For example, Article 12(2) merely requires member states to "give due regard to the desirability of avoiding discrimination as between foreign investments." See INTERNATIONAL INVESTMENT INSTRUMENTS, supra note 20, at Annex A (reproducing investment related provisions in regional free trade and integration agreements); THOMAS L. BREWER \& STEPHEN YOUNG, THE MULTILATERAL INVESTMENT SYSTEM AND MULTINATIONAL ENTERPRISES 67 (1998) [hereinafter BREWER \& YOUNG] (discussing the Czech government's objection to granting equal status to German investors).

24 See Sylvia Ostry, Looking Back to Look Forward: The Multilateral Trading System After 50 Years, in FROM GATT TO THE WTO: THE MULTILATERAL TRADING SYSTEM IN THE NEW MILLENNIUM 97 (2000) (detailing American objections to the regulation of the anti-competitive behavior of private enterprises). 
foreign investment between developed and developing countries..$^{25}$ As many developing countries gained political independence, rates of expropriation of foreign investment increased markedly. ${ }^{26}$ Developed states sought ways in which to protect their investors from the increased threat of expropriation. The conclusion of BITs between developed and developing countries became a primary tool for effectuating this goal. A core component of most BITs are strong provisions on investment protection and particularly, the guarantee of compensation by the host state in the event of expropriation of investment.27 Despite the reduction in expropriatory behavior in recent years, ${ }^{28}$ the exceptionally strong investment protection provisions in later initiatives such as NAFTA and the MAI continue to reflect the preoccupation with the hostile attitude of developing countries towards foreign investment in the late 1960s.

By the end of the 1970s, the international policy landscape on investment had shifted with a particular impact on developing countries. The debt crisis of the 1980s limited the supply of loan finance to excessively indebted developing states and made FDI a more desirable source of foreign capital. In addition, the process of developing states acquiring control over their natural resources had progressed since the immediate post-war period and was no longer a strong priority. The risk of large-scale expropriation of foreign investment in these countries significantly diminished. ${ }^{29}$

25 See generally UNCTAD, WORLD INVESTMENT REPORT 1996: INVESTMENT, TRADE AND INTERNATIONAL POLICY ARRANGEMENTS 147-48, figs. V.2-V.3 (1996) [hereinafter WORLD INVESTMENT REPORT 1996] (charting the exponential growth of BITs from 1959 to 1996). From under 200 BITs completed by the end of the 1960s, the number of BITs had grown to a total of 1941 at the end of 2000 . WORLD INVESTMENT REPORT 2001, supra note 9, at 6-7.

26 BREWER \& YOUNG, supra note 23 , at 53 . Table 2.3 summarizes trends in expropriation from 1960 to 1992 . For example, the mean number of expropriations in 1960-64 was 11, in 1965-69 it was 16, in 1970-74 it was 51, in 1975-79 it was 34 , in 1980-84 it was 3, in 1985-89 it was 0.4, and in 1990-92 it was 0.

27 For a discussion of the typical investment protection provisions in BITs that provide for compensation in the event of expropriation, see DOLZER \& STEVENS, supra note 2 , at $97-117$.

28 See supra text accompanying note 26. See generally Michael S. Minor, The Demise of Expropriation as an Instrument of LDC Policy 1980-1992, 25 J. INT'L Bus. STUD. 177 (1994) (discussing the reduction of expropriation amongst developing countries).

29 For evidence of the decline in direct expropriatory behavior, see supra text accompanying note 26 . Threats to expropriate foreign investment, however, continue to occur on occasion. A recent example was the threat by President Robert Mugabe of Zimbabwe to expropriate foreign-owned mines in the lead-up to Zim- 
Indeed, contemporary independence movements have even begun to forge links with foreign investors to ensure economic viability in the event that an independent state is formed as a result of their movement. ${ }^{30}$ Thus, the interests of developing countries have shifted away from an attitude of hostility regarding foreign investors towards the need to attract and retain FDI. At the national level, numerous countries were taking unilateral steps to liberalize restrictions on the entry and operation of FDI. ${ }^{31}$ In recent years, especially since the Asian financial crisis of 1997-1998, developing countries have found FDI to be more stable than short-term portfolio investment and bank lending. FDI inflows remained almost unchanged during the crisis in the five most seriously affected Asian countries, when other private capital flows, such as bank loans and debt securities, fell dramatically. ${ }^{32}$ The trend of liberalization at the national level was also mirrored at the bilateral level. The 1990s witnessed the strongest growth in the conclusion of

babwe's parliamentary elections in June 2000. Ed O'Loughlin, Mugabe Turns His Sights to Business, AGE (Melbourne, Austl.), June 17, 2000, at 27.

30 This was evidenced in the recent discussions between the Council of OPM (Free Papua Organization) - which is campaigning for independence for the Indonesian province of Irian Jaya - and investors in Irian Jaya including Freeport (one of the world's largest mining companies). The attitude of OPM towards investors and investor certainty in Irian Jaya is illustrated by the following statement by Mr. Franzalbert Joku, the international moderator for OPM:

We are talking about establishing a modern and viable State, and to do that we have to deal with developers. Any sensible leader would want to see such relationships continue. We are already holding discussions with Freeport and other investors, present and potential. The business world is very sensitive to the kind of events unfolding in West Papua and wants to see its interests protected. We shall do everything possible, in our power and within reason, to see this happens.

Rowan Callick, Independence Leader Forges Links with Foreign Investors, AUST. FIN. REV., Jan. 12, 2001, at 24.

31 See UNCTAD, WORLD INVESTMENT REPORT 1999: FOREIGN DIRECT INVESTMENT AND THE CHALLENGE OF DEVELOPMENT 115 (1999) [hereinafter WORLD INVESTMENT REPORT 1999]. Table IV.1 charts the changes in national regulation of FDI in various developed and developing countries from 1991 to 1998. The table shows that $94 \%$ of the regulatory changes made during this period were in the direction of creating a more favorable environment for FDI. But within this broad trend, there can exist a gulf between the form and effect of the liberalization measure. For example, in Laos, the government recently lifted a rule requiring every foreign investment-no matter how small-to be approved by the Prime Minister. Despite this change, regulatory approvals for foreign investment projects in Laos still typically take over a year to complete. Wayne Arnold, Mining Gold in Laos Where Bombs Once Rained, N.Y. TMES, Mar. 5, 2002, at C8.

32 WORLD INVESTMENT REPORT 1999, supra note 31, at 9, 20-23. 
BITs. The total number of BITs had reached 1941 by the end of 2000.33

The 1990s were also characterized by a strong push to conclude regional rules to liberalize investment flows. Of these various regional initiatives, NAFTA Chapter 11 is notable for setting extremely high standards for investment liberalization, investment protection, and dispute settlement. By comparison, little attention was given to investment issues at the multilateral level until the mid-1980s. An attempt by the United States to include investment on the GATT Tokyo Round negotiations (1973-1979) failed due to the opposition of developing countries. ${ }^{34}$ In the lead-up to the Punta del Este GATT Ministerial Meeting in March 1986, the United States again put forward a proposal for a comprehensive agreement on investment in the GATT. ${ }^{35}$ This approach was resisted by developing countries ${ }^{36}$ with the resulting compromise to limit negotiations to "trade-related investment measures." Developing countries (with some exceptions) also opposed the U.S. proposal to include trade in services in the negotiations. ${ }^{37}$ However, these countries eventually agreed to the inclusion of trade in services in the Punta del Este declaration on condition that negotiations in that area would take place on a separate track from those on goods, with a clear development orientation. ${ }^{38}$

33 See supra text accompanying note 25.

34 See BREWER \& YOUNG, supra note 23, at 122 ("Despite its efforts, however, the USA was not successful in getting investment issues on the agenda of the GATT Tokyo Round Negotiations (1973-79). Developing countries had been particularly resistant....").

35 See generally THE GATT URuguay Round: A Negotiating History 2069 (Terence P.Steward ed., 1993) [hereinafter GATT URUGUAY ROUND]

(On June 10, 1986, the United States introduced a proposed text for the ministerial declaration on investment. This document reviewed the importance of investment issues to international trade; past GATT actions related to investment measures ... the competence of the GATT to establish and oversee a multilateral agreement on investment measures, as well as proposals to define the scope of an agreement.).

36 See id. at 2070 ("The goals of the [first draft ministerial declaration] reflect the views of several South American and other developing countries already presented to the Preparatory Committee, namely that GATT negotiations should be restricted to trade in goods, not services, or policy-related issues such as investment regulation and intellectual property rights.").

37 GATT URUGUAY ROUND, supra note 35, at 2354-58.

38 See Murray Gibbs \& Mina Mashayekhi, The Uruguay Round Negotiations on Investment: Lessons for the Future I 16 (UNCTAD, May 14, 1998) (discussing developing countries' concessions in the Punta del Este declaration). 
By the end of the Uruguay Round negotiations in 1994, only two of the final fifty legal instruments to result included direct provisions dealing with foreign investment issues. These were the Agreement on Trade-Related Investment Measures" ("TRIMS Agreement") and the GATS. ${ }^{40}$ Both of these agreements only deal with investment in a fragmented manner adopting an issue- or sector-specific approach. The TRIMS Agreement focuses only on the imposition of certain performance requirements on an investor after entry into the host state. Whilst the GATS ostensibly pertains to "trade in services," 41 it also contains detailed provisions concerning foreign investment. This reflects the fact that FDI tends to be especially important in service industries, as it is a way for firms to enter and service a foreign market. Indeed, "trade in services" is defined as including the supply of services "by a service supplier of one Member, through commercial presence in the territory of any other Member." 42 FDI, through "commercial presence," is thereby included as one of the modes of supply of services covered by the GATS.

The system that emerged by the mid-1990s can be thus described as a patchwork of international rules on foreign investment. Strong provisions on investment liberalization and protection are particularly evident at the bilateral and regional levels. The emphasis on investment protection in these instruments reflects the hostile attitude of host states and the attendant expropriatory behavior evident in the late 1960s. Since then, developing countries have adopted a more welcoming attitude to FDI as a source of development capital. However, the Uruguay Round negotiations evidence the traditional resistance of developing countries towards attempts to include investment on the GATT/WTO negotiating agenda. This is perhaps not altogether surprising given the record of increasing investment flows that do not appear to correlate to the absence of multilateral rules on investment.

The next Section will examine the way in which states typically regulate the entry and operation of investors. The central focus

39 Agreement on Trade-Related Investment Measures, April 15, 1994, Marrakesh Agreement Establishing the World Trade Organization, Annex 1A, LEGAL INSTRUMENTS-RESULTS OF THE URUGUAY ROUND (1994) [hereinafter TRIMS], available at http://www.wto.org/english/docs_e/legal_e/18-trims.pdf.

40 GATS, supra note 19.

41 Id. art. I(1).

42 Id. art. $I(2)(c)$. 
will be to identify what potential advantages would accrue to developing states from the liberalization of these regulatory measures in a potential WTO investment agreement.

\section{HOST STATE REGULATION OF FOREIGN INVESTMENT}

The range of policies used by host states to regulate foreign investment is immense. Once a foreign investor enters into a host state, it becomes subject-like any domestic party-to the full range of regulatory measures passed by the host state. But within this broad category, there are normally measures that discriminate (in a positive or negative sense) between foreign and domestic participants in the market. These discriminatory measures are what most international investment agreements attempt to discipline. However, as Section 4 of this Article will show, foreign investors have become recently active under Chapter 11 of NAFTA in challenging even seemingly non-discriminatory regulatory measures.

At this stage, it is possible to categorize most discriminatory forms of national regulation of foreign investment into one of three categories: (i) pre-admission restrictions on establishment of foreign investment; (ii) post-admission restrictions once the foreign investor has entered the host state; and (iii) incentives to attract foreign investors into the host state. Vastly different rationales exist for imposing these different categories of restrictive measures. WTO negotiators will need to carefully consider these different rationales as a means in which to judge the political appetite of member states to the depth of coverage of a WTO investment agreement.

\subsection{Pre-Admission Restrictions: The Political Sphere}

States have traditionally imposed restrictions over the admission of foreign goods, services, and capital. In recent years, the GATT and later WTO agreements have significantly reduced barriers to trade in goods (such as tariffs) and to a lesser extent, barriers to trade in services. Despite this powerful trend towards trade liberalization, states at all stages of the development process still retain some restrictions on the admission of foreign investors. These restrictions can take various forms ${ }^{43}$ such as closing certain sectors

43 For a comprehensive list of the myriad of forms of restrictions on admission, see WORLD INVESTMENT REPORT 1996, supra note 25, at 176-77. 
of a nation's economy to $\mathrm{FDI}, 44$ quantitative restrictions on the number of foreign investors admitted into a specific sector, and screening and registration procedures. 45 These admission restrictions are often connected to sovereignty concerns based on the perceived harm believed to flow from ownership of a country's productive resources by foreign investors. These political concerns cannot be understated and apply to host states at all stages of development (albeit at different levels).

Even some developed states still exclude the entry of FDI into strategic sectors such as media, publishing and films, and other core industries involved in national defense and security. ${ }^{46}$ These restrictions are more substantive for developing countries because many of these countries only began to orientate their domestic policies toward FDI in the late 1970s. For developing countries, the tension between modernizing their economies through the admission of foreign investment and the desire to retain control over strategic economic sectors is a constant one. ${ }^{47}$ This raises an impor-

44 For example, the version of the Indonesian Negative Investment List issued by Presidential Decree on July 2, 1998, excludes foreign investment in sectors such as freshwater fish, forest utilization, local shipping, taxi and bus transport, and medical services. See OECD PROCEEDINGS, FOREIGN DIRECT INVESTMENT AND RECOVERY IN SOUTHEAST ASIA (1999).

45 For example, proposals by foreign investors to invest in Australia over certain monetary thresholds require notification to the Australian Foreign Investment Review Board. That Board will examine proposals to acquire existing business (with total assets over AUD $\$ 50$ million) and will raise no objection to a proposal unless it is "contrary to the national interest." Foreign Acquisitions and Takeovers Act, 1975, c. $\$ \$ 18-21$ a (Austl.) (and accompanying Ministerial statements).

46 For a comprehensive analysis of the exclusion of national defense and security sectors from the entry of FDI into the United States, see MichaEL J. TREBILCOCK \& ROBERT HOWSE, THE REGULATION OF INTERNATIONAL TRADE 342-44 (2d ed. 1999); David Scott Nance \& Jessica Wasserman, Regulation of Imports and Foreign Investment in the United States on National Security Grounds, 11 MICH. J. INT'L L. 926 (1990).

47 For a very recent example of this tension, see Tim Weiner, As National Oil Giant Struggles, Mexico Agonizes over Opening It to Foreign Ventures, N.Y. TIMES, Feb. 17, 2002, at 6. After nationalization of Mexico's oil operations in 1938, the Mexican Constitution was amended to forbid foreign exploitation of its oil and gas reserves. Mexico's state-run energy company, Pemex, was at one time a symbol of nationalistic pride. "Schoolchildren still learn that the creation of Pemex after the oil expropriation was the culmination of their nation's independence." Id. But, in recent years, it has also been used as a source of lucrative funds for the Mexican government. Taxes and duties on Pemex finance more than one-third of the Mexican federal budget. Faced with increasing pollution and a poor safety record, the current President, Vicente Fox, is considering modernizing the company by allowing some foreign participation. But the opposition to change at $\mathrm{Pe}-$ 
tant but sometimes overlooked point. In the realm of foreign investment, political and economic considerations interact very closely. Put simply, foreign investment (as a means of long-term ownership of national assets and resources) is much more politically sensitive than foreign trade.48 This political sensitivity is heightened by the manner in which liberalization is effected in the foreign investment sphere. Trade restrictions, such as tariffs, can be reduced incrementally, and the value of those reductions can be translated relatively easily into a common denominator. ${ }^{49}$ This is much more difficult in the context of regulatory impediments to foreign investors.

These sovereignty concerns have shaped the structure of most pre-MAI investment agreements. Within most international investment regimes, it is generally only Chapter 11 of NAFTA and BITs involving the United States that explicitly apply the nondiscriminatory norms of national and most-favored-nation treatment to the entry of foreign investment. 50 In contrast, most nonU.S. BITs reserve the right of the host state to regulate the entry of foreign investors and only apply liberalization conditions to the post-establishment phase of the investment process. 51

mex remains a powerful force with the fear that Mexico's prime natural resource might once again be used to enrich foreigners.

48 This point is argued forcefully by A.V. Ganesan, a former Commerce Secretary to the Government of India. See A.V. Ganesan, Developing Countries and a Possible Multilateral Framework on Investment: Strategic Options 7 (2) TRANSNAT'L CORP. 1 (1998).

49 For an overview of the mechanics, negotiating techniques, and reciprocity criterion for reducing tariffs, see BERNARD M. HOEKMAN \& MICHEL M. KOSTECKI, The Political Economy of THE WORLd TRading System: THE WTO and Beyond 122-33 (2001).

50 NAFTA, supra note 3, arts. 1102-04. Under these articles, each NAFTA state must provide the better of national and most-favored-nation treatment to investors of another NAFTA state "with respect to the establishment, acquisition, management, conduct, operation, and sale or other disposition of investments" (emphasis added). The reference to "establishment, acquisition" explicitly includes the admission phase of the investment process.

51 Agreement for the Promotion and Protection of Investments, Mar. 14, 1994, Ind.-U.K., vol. 34, 34 I.L.M. 935, 941. Unlike NAFTA, under Article 4(1) of this BIT, there is no explicit reference to wording such as "establishment" or "acquisition." Instead, each contracting party is required to provide national treatment to investments of investors of the other party dealing with "their operation, management, maintenance, use, enjoyment or disposal by such investors." See DOLZER \& STEVENS, supra note 2, at 53-85 (examining the differences in the treatment of admission of foreign investors in various BITs); INVESTMENT AGREEMENTS IN THE WESTERN HEMISPHERE: A COMPENDIUM 19 (1999). 


\subsection{Post-Admission Restrictions: Capturing Economic Gains}

Once a foreign investor is permitted to enter the host state, restrictions can still be imposed on the ownership or operation of the foreign investment. But most of these restrictions are designed to capture the economic benefits of the investment process rather than on sovereignty grounds. The range of post-admission restrictions is enormous, ${ }^{52}$ and it encompasses techniques as diverse as compulsory joint ventures with host state participation to performance requirements on the operation of the foreign investment. Performance requirements deserve particular emphasis given their inclusion in the TRIMS Agreement. These are conditions imposed on investors (often linked to the grant of an incentive by the host state), such as local content requirements (mandating that products produced by the investor in the host state contain a certain level of local materials), the employment of local personnel, and mandatory technology transfer (often through compulsory licensing requirements). 53

As a home state for many of the world's TNCs, it is not particularly suprising that the United States has long been an advocate for the elimination of performance requirements. ${ }^{54}$ In fact, the economic case for liberalizing these restrictions is, on first view, very strong. Some performance requirements may restrict economic growth in host states by acting as a disincentive to the entry of investors. For example, a common objective in imposing joint venture requirements on the entry of investors is the hope of achieving greater technology transfer to host states. One effect of this requirement is that it may discourage investors whose proprietary technology is a significant asset and one which they are reluctant to share with other (and potentially rival) firms. A large body of research has found that these requirements do not in fact lead to the objective of enhancing the transfer of technology to the host state. .55

52 For a detailed list, see WORLD INVESTMENT REPORT 1996, supra note 25, at 177-79.

53 TRIMS, supra note 39.

54 See, e.g., COMMISSION ON U.S.-PACIFIC TRADE AND INVESTMENT POliCY, BUILDING AMERICAN PROSPERITY IN THE 21ST CENTURY: U.S. TRADE AND INVESTMENT IN THE ASIA PACIFIC REgION 20-22 (1997) [hereinafter BuILDING AMERICAN PROSPERITY] (criticizing various performance requirements imposed by Japan, China, Malaysia, Indonesia, South Korea, and the Philippines).

55 For a summary of the empirical work conducted by economists on the effect of performance requirements, see Theodore H. Moran, Foreign Direct Investment and Development: A Reassessment of the Evidence and Policy Implications, 
The research shows that technology transferred to joint ventures is significantly older, and the speed of upgrading is slower than to wholly-owned subsidiaries of investors. 56 But the evidence is not absolute for all forms of performance requirements. ${ }^{57}$ In contrast, local content requirements are often imposed in an attempt to develop clusters of industries in a given country. ${ }^{58}$ These clusters are groups of industries that are interdependent, and according to a prominent theory of industrial competitiveness, contribute significantly to a host state's economic development. ${ }^{59}$ When an investor enters a host state, it may continue to simply source its inputs from its home base. The imposition of local content requirements is often intended to counteract this tendency by ensuring that clusters of local manufacturers (supporting the foreign investor's activities) develop in the host state.

Whilst this is by no means an exhaustive analysis of the economic effects of the large range of performance requirements, it does militate against the conceptual trap of treating all of these requirements as welfare-reducing for both home and host states. Indeed, it is clear that some developing countries have underestimated the relatively limited impact of the Uruguay Round TRIMS Agreement on their use of performance requirements. ${ }^{60}$ In the con-

Article presented at the OECD Conference on the Role of International Investment in Development, Corporate Responsibilities and the OECD Guidelines for the Multinational Enterprises (Sept. 20-21, 1999).

56 Id.

57 For an analysis of situations in which export performance requirements may increase host state welfare, see Dani Rodrik, The Economics of ExportPerformance Requirements, 102 Q. J. ECON. 633 (1987) (analyzing the resource allocation and welfare effects of export performance requirements imposed on foreign investors). See also Patrick Low \& Arvind Subramanian, Beyond TRIMS: A Case for Multilateral Action on Investment Rules and Competition Policy?, in THE URUGUAY Round and the Developing Countries 380-88 (Will Martin \& L. Alan Winters eds., 1996).

58 See TREBILCOCK \& HowSE, supra note 46 , at 338-39.

59 Id.

60 The Annex to the TRIMS Agreement sets out an "Illustrative List" of performance requirements that are inconsistent with the agreement. The agreement provides for notification, national treatment, and the phased elimination of this limited set of performance requirements. In early 2000 (which marked the expiration of the transition period for the elimination of TRIMS for developing countries), a group of developing countries began to lobby the WTO Council for Trade in Goods for an extension to the transition period. In July 2001, an agreement was reached whereby the requests of nine countries - Argentina, Chile, Colombia, Malaysia, Mexico, Pakistan, the Philippines, Romania, and Thailand - were to be 
text of a future WTO investment agreement, it is likely that developing countries will resist strengthened disciplines in this area without some corresponding concession to their interests in the Doha negotiations. Section 6 of this Article will examine the scope of the Doha agenda to deliver concessions to developing countries in issues other than investment. Aside from this sort of cross-issue linkage as a means of achieving consensus in the Doha negotiations, the WTO negotiators will also need to consider possible intra-issue tradeoffs within the general topic of investment. One possible solution may be to link further disciplines on postadmission restrictions in a WTO investment agreement with new disciplines on the use of investment incentives by host states. ${ }^{61}$ The role of investment incentives in national investment policies and the relative disadvantage of developing countries in the use of incentives is considered next.

\subsection{Incentives: A Competitive Dilemma}

Incentives to attract investors into the host state are often linked to performance requirements by host states. In other words, they act as an economic carrot to sweeten the imposition of the stick.62 The range of incentives offered by host states is extensive. However, there are broadly two main categories - fiscal incentives (whose objective is often to reduce the tax burden for an investor by, for example, reducing the standard corporate income tax rate) and financial incentives (which normally involve the provision of funds directly to the investor in the form of direct subsidies, loan guarantees, or export credits). ${ }^{63}$ Developed states normally favor the use of financial incentives over fiscal ones, in part because fiscal incentives generally require change to domestic legislation and

granted extensions to be approved by the Goods Council by October 2001. However, opposition from the United States and Canada to the detail of the Malaysian and Colombian plans to phase out non-conforming measures prevented an agreement from being reached in October 2001. Rift over Malaysia, Colombia Holds Up Approval of TRIMS Extensions 19 (42) INSIDE U.S. TRADE 11, 12 (Oct. 19, 2001).

61 This type of grand bargain has oft been mooted, but, because of its importance, it deserves reconsideration and analysis. E.V.K. Fitzgerald, Developing Countries and Multilateral Investment Negotiations, in MULTLATERAL REGULATION OF INVESTMENT 60-62 (E.C. Nieuwenhuys \& M.M.T.A. Brus eds., 2001).

62 For a useful analysis of the linkage between performance requirements and investment incentives at the national level, see Rachel McCulloch, Investment Policies in the GATT, 13 WORLD ECON. 541, 545-48 (1990).

63 For a concise summary of the range of incentives used by host states, see WORLD INVESTMENT REPORT 1996, supra note 25, at 180. 
hence parliamentary approval. In contrast, developing states tend to prefer the use of fiscal incentives, as they generally lack the resources needed to provide direct financial incentives. ${ }^{64}$

There are various theoretical arguments used by host states to justify the issue of incentives.65 In particular, host states view the use of these incentives as a means of influencing the decisions of investors to locate in a particular region. The assumption is that this relocation can lead to associated investments by other investors, thus creating roll-on benefits for the host state. Ultimately, however, these incentives may only be successful to the extent that they succeed in attracting investment from one state into another. As such, there is a real risk of competition amongst states in the use of incentives. ${ }^{66}$ In such competition, it is obviously the poorer countries that are relatively disadvantaged. In a bidding contest using fiscal and financial incentives, the winner is likely to be the country that has the "deepest pockets." 67 The use of incentives can thereby act to distort the allocation of global FDI (based, in part, on the comparative advantages of host states), particularly discriminating against developing countries. Somewhat ironically, the empirical evidence suggests that incentives only play a limited role in the decisions of investors to invest among different states. ${ }^{68} \mathrm{In}$

64 A typical example of the use of fiscal incentives occurred recently in Laos to attract the development of a gold mine by Oxiana Resources, a small Australian mining company. See Arnold, supra note 31, at C8

(As incentives, Laos has exempted Oxiana from corporate taxes for two years as well as its employees from having to pay income taxes. It has waived duties on imported equipment and is permitting Oxiana to hire a customs official to be posted on site, eliminating long waits for shipments at the border.).

65 For a theoretical analysis of the use of incentives, see UNCTAD, INCENTIVES AND FOREIGN DIRECT INVESTMENT 9-16 (1996) [hereinafter INCENTIVES AND FOREIGN DIRECT INVESTMENT].

66 For example, during the course of 1996-2000, General Motors entered into negotiations for the construction of a new U.S. \$250 million engine plant with five possible suitors: Brazil, Germany, Sweden, and two Australian sub-federal states, South Australia and Victoria. Towards the end of negotiations, only Victoria and South Australia remained as suitors. Eventually, Victoria's bid of U.S. $\$ 30$ million (in comparison to South Australia's bid of U.S. \$12 million) succeeded in attracting General Motors to locate the plant in Victoria. Holden's Decision, AGE (Melbourne, Austl.), Dec. 14, 2000, at 4.

67 INCENTIVES AND FOREIGN DIRECT INVESTMENT, supra note 65, at 14.

68 In a 1984 survey of 52 TNCs, out of 19 factors identified by TNCs as influencing their decision to invest in a host state, incentives offered by the host state ranked seventh in importance for investments in developing states and eighth in developed states. GROUP OF THIRTY, FOREIGN DIRECT INVESTMENT 19731987: A SURVEY OF INTERNATIONAL COMPANIES (1984). See also INCENTIVES AND 
this respect, instead of enabling wealthy countries to attract investors, some incentives may simply act as a form of wealth transfer from the host state to the investor.

Unlike the restrictions considered earlier, there are effectively no rules at the international level to discipline the use of investment incentives. ${ }^{69}$ The foregoing analysis suggests clear benefits to developing countries in the negotiation of rules limiting the use of incentives given their relative disadvantage in any bidding context using incentives. But, given political realities, it will be more difficult for developed countries to agree to such rules.70 If the developed world simply accepts the economic evidence of the distortive effects of incentives, then incentive competition would constitute a "prisoner's dilemma" for the world as a whole (instead of only implying losses for developing countries). In turn, this would create impetus for all states to act co-operatively to design rules limiting the use of incentives.

But it is more likely that developed countries will continue to oppose the inclusion of incentives in negotiations rules on FDI. Aside from the perceived success of incentives in some developed

SURVEY OF INTERNATIONAL COMPANIES (1984). See also INCENTIVES AND FOREIGN DIRECT INVESTMENT, supra note 65 , at 10 (discussing using incentives to attract TNCs); Edward M. Graham, Trade and Investment in the WTO: Just Do It!, in LAUNCHING NEW Global TRADE TALKS: AN ACTION AGENDA 151-64 Jeffrey J. Schott ed., 1998). But cf. Bernard Hoekman \& Kamal Saggi, From TRIMS to a WTO Agreement on Investment?, in DEVELOPING COUNTRIES AND THE WTO: A PRO-ACTIVE AGENDA 206-07 (Bernard Hoekman \& Will Martin eds., 2000) (questioning the rationale for disciplines on all incentives).

69 OECD, THE OECD DEClaRATION ON INTERNATIONAL INVESTMENT AND MultinATIONAL ENTERPRISES 1976 (OECD, Working Paper No. 20, 1997) (as reviewed and amended). This Declaration comprises a Statement on National Treatment, a Statement on International Investment Incentives and Disincentives and a set of voluntary Guidelines for Multinational Enterprises. "The Statement on International Incentives and Disincentives enables a member state to consult with another member state when it considers that its interests may be adversely affected by the impact of ... official incentives and disincentives to international direct investment." However, to date, little consultation has taken place, as few OECD states have wanted to take the competitive risk of exposing their use of incentives. See generally OECD, THE OECD DECLARATION AND DECISIONS ON INTERNATIONAL INVESTMENT AND MULTINATIONAL ENTERPRISES: 1991 REVIEW (1992).

70 One particular aspect of the political sensitivity of developed states to disciplines on the use of incentives arose in the MAI negotiations. The United States opposed the inclusion of the use of sub-national incentives in the negotiations on the basis that it could (or should not) bind state governments to obligations regarding incentives. See Graham, supra note 68, at 153. 
home states, 71 the political economy aspect of this issue would most likely see the business community of developed home states (as losers from such rules) lobby vigorously against this proposal. A more realistic approach to limits on incentives is that of, at least in perception, a zero-sum game that would increase welfare in developing countries but reduce welfare in developed states.

However, there is still clearly room in a WTO initiative to create an incentive for WTO members to cooperate in this area. In essence, this would involve linking disciplines on incentives to that of performance requirements. An offer by developed states to consider rules on incentives could act as a powerful inducement for developing countries in turn to agree to other restrictions in such a general agreement. This type of reciprocal, intra-issue linkage is precisely what may be needed to overcome the resistance by developing countries to general rules on investment.

Reciprocity within and across issues is not the only strategy that will need to be pursued by negotiators to guarantee the success of any WTO investment agreement. Aside from disciplines on directly discriminatory measures such as those explored above, the WTO negotiators will also need to consider the delicate balance between investment rules and legitimate regulatory measures with an incidental impact on foreign investors. The difficulty in drawing a line between effective investment rules and broader host state regulatory autonomy is best illustrated by on-going difficulties under Chapter 11 of NAFTA. These will be considered next.

\section{THE NAFTA CHAPTER 11 MODEL}

In considering prospects for a WTO investment agreement, an analysis of Chapter 11 of NAFTA is essential for three reasons. First, NAFTA Chapter 11 contains the most detailed and comprehensive rules on foreign investment in any international treaty. Second, the drafters of the MAI relied heavily on the NAFTA provisions when formulating the substantive provisions of the MAI. This leads to the obvious point that the WTO member states are likely to look to the NAFTA experience when considering whether and how to negotiate WTO investment rules. Third, there has been an explosion in recent years in the number of arbitral challenges

71 For example, Ireland has used a variety of financial incentives in its successful campaign to attract FDI and develop its computer and electronic sector. UNCTAD, WORLD INVESTMENT REPORT 1998: TRENDS AND DETERMINANTS 105 (1998). 
brought by investors under Chapter 11 against regulatory measures imposed by NAFTA states. Chapter 11 is arguably the best tool available to consider the way in which to frame the delicate relationship between a multilateral investment agreement and regulatory autonomy. In particular, such an analysis enables a normative assessment of the advantages or otherwise of using a Chapter 11 NAFTA model as a guide for a WTO investment agreement on this question.

\subsection{Overview}

There are four essential components to Chapter 11 of NAFTA: scope of application, investment liberalization, protection, and dispute settlement. Of the discriminatory measures considered in Section 3 of this Article, the NAFTA Chapter 11 model primarily aims to discipline the use of pre- and post-admission restrictions by a NAFTA state. In comparison, there are few provisions limiting the use of investment incentives.

\subsubsection{Scope of Application: Article 1101}

The coverage of the substantive provisions of NAFTA is delineated by Article 1101. This provides two separate planes of application. First, all the Chapter 11 disciplines apply to measures of a NAFTA state relating to "investors" of a NAFTA state and to "investments" by investors of a NAFTA state. In addition, the particular disciplines in Article 1106 (Performance Requirements) and 1114 (Environmental Measures) apply to all investments (that is, including domestic investments and investments from nonNAFTA countries).

The key definition in appreciating the coverage of Chapter 11 of NAFTA is that of "investment" in Article 1139. The NAFTA model adopts a very broad, asset-based definition of "investment" extending to most forms of capital such as equity security, debt security, debt finance and real estate in a NAFTA country. Indeed, the NAFTA approach goes beyond FDI to include portfolio investment by virtue of the fact that "equity security" is included in limb (b) of the definition without any percentage limitation on ownership. This is also bolstered by $\operatorname{limb}(\mathrm{e})$ of the definition, which would go beyond direct ownership of equity security (where the quantum of ownership is not sufficient to characterize the investment as FDI) to include beneficial ownership of the un- 
derlying interest (through, for example, holding units in a listed investment trust). ${ }^{72}$

But there are tendencies within the interpretation that counter this broad approach. First, the Article 1139 definition sets out an exhaustive list of interests that would qualify as an investment. ${ }^{73}$ Even within this list, there are limiting factors within the definition of certain interests. For example, loan finance is only covered under item (d) of the definition if the loan is made to an enterprise that is an affiliate of the investor or where the original maturity of the loan is at least three years. Thus, this approach only covers intra-firm debt flows or debt with a relatively long-term perspective. In other words, the NAFTA approach explicitly excludes shorterterm debt (whose volatility led to liquidity problems in the Asian financial crisis) from attracting the benefit of the disciplines in Chapter 11.74 A similar theme is evident in item (h) of the definition, which tries to isolate key characteristics of an investment not necessarily related to an enterprise (whether through equity or debt) or real estate. Item (h) of the definition of "investment" in Article 1139 includes:

Interests arising from the commitment of capital or other resources in the territory of a Party to economic activity in such territory such as under contracts involving the presence of an investor's property in the territory of the Party, including turnkey or construction contracts; or contracts where remuneration depends substantially on the production, revenues or profits of an enterprise..$^{75}$

This approach of trying to identify the characteristics of an investment (thereby delineating what forms of capital get the benefit of Chapter 11) is also bolstered by the limited exclusions to the

72 NAFTA, supra note 3, art. 1139. Limb (e) of the definition of "investment" includes "an interest in an enterprise that entitles the owner to share in income or profits of the enterprise" (emphasis added).

73 NAFTA, supra note 3, art. 1139 (stating what "investment" means). In comparison, the MAI definition was much broader by adopting a non-exhaustive list of interests that would qualify as an investment.

74 See infra Section 5.1. for an examination of the volatility of loan finance and portfolio investment (when compared to FDI) in the Asian financial crisis of 1998 in the context of the MAI negotiations.

75 NAFTA, supra note 3, art. 1139(h). 
definition of "investment" in items (i) and (j) of Article 1139. These are essentially claims to money arising from trade in goods or services or related forms of financing (such as trade financing).

\subsubsection{Investment Liberalization: Articles 1102 to 1104 and 1106}

The first substantive discipline on national measures affecting investors and investments of a NAFTA state are the liberalization commitments in Chapter 11. Liberalization is effected primarily through the application of non-discriminatory standards of treatment. But the NAFTA model is a typically American conception of non-discrimination as applied to investment restrictions. Like most BITs involving the United States, investors are provided with the better of national and most-favored nation treatment, which extend to both proposed investments (pre-admission) as well as established investments in a NAFTA state (post-admission). ${ }^{76}$ The extension of liberalization commitments to the pre-establishment phase is a striking aspect of NAFTA and one, which separates it from other international initiatives such as the Energy Charter Treaty. ${ }^{77}$ The top-down structure of NAFTA Chapter 11 means that these substantive commitments cover all economic sectors and national laws of a NAFTA state unless specifically exempted by the submission of a negative-list of non-conforming measures. ${ }^{78}$ In contrast to this strict approach, the GATS adopts a hybrid structure, which involves elements of a bottom-up approach. WTO members can either make horizontal commitments (across all services sectors) or sector-specific commitments (which cover a par-

76 NAFTA, supra note 3, arts. 1102 (National Treatment), 1103 (Most-FavoredNation Treatment) \& 1104 (Standard of Treatment). The obligation to accord national and most-favored-nation treatment to the proposed investments is indicated by the inclusion of the words 'establishment' and 'acquisition' in Articles 1102 and 1103.

$\pi$ In the negotiations towards the Energy Charter Treaty from 1992 to 1994, the negotiators could not agree on a binding regime for the pre-admission phase and decided to postpone the negotiation of such a regime to a supplementary stage. Instead, under the pre-admission phase, member states are subject to a soft law, best efforts obligation under Articles 10(2) and 10(3). In comparison, investors are provided with full national and most-favored-nation treatment in the post-admission phase under Article 10(7). See Thomas W. Wälde, Introductory Note, European Energy Charter Conference: Final Act, Energy Charter Treaty, Decisions and Energy Charter Protocol on Energy Efficiency and Related Environmental Aspects vol. 34, 34 I.L.M. 360, 361-62 (1995) (delineating the historical development of the Energy Charter). IV.

78 NAFTA, supra note 3, art. 1108 (Reservations and Exceptions), annexes I- 
ticular economic sector) to the national treatment obligation in $\mathrm{Ar}$ ticle XVII. This complicated structure provides WTO members with significant discretion in determining in what manner to open up their service sectors to foreign competition. However, analyses to date of commitments scheduled under the GATS show only limited results in effecting liberalization in the services area. ${ }^{79}$

The NAFTA liberalization commitments extend beyond imposing non-discriminatory standards of treatment to encompass an outright prohibition on the use of certain performance requirements by NAFTA member states. ${ }^{80}$ In this respect, the NAFTA provisions go beyond the WTO approach in the TRIMS Agreement. The NAFTA list of prohibited performance requirements includes, for example, technology transfer requirements that are not explicitly covered by the TRIMS Agreement.81 Article 1106 is also the only part of Chapter 11 to deal with the use of investment incentives. Of itself, Article 1106 does not prevent a NAFTA party from using incentives. It simply restricts their ability to link the use of incentives to certain performance requirements. ${ }^{82}$

\subsubsection{Investment Protection: Articles 1110 and 1105}

Like most investment agreements, NAFTA contains specific rules on investment protection. Section 2.2 of this Article traced the development of guarantees of investment protection in BITs to the incidents of increased expropriation of investments in the wake of decolonization efforts in the 1960s. The actual content of these guarantees have been the subject of divergence of opinion between developed and developing countries. ${ }^{83}$ Nonetheless, investment

79 See, e.g., Bernard Hoekman, Assessing the General Agreement on Trade in Services, in THE URUGUAY ROUND AND THE DEVELOPING COUNTRIES 88-124 (Will Martin \& L. Alan Winters eds., 1996) (summarizing the main elements of GATS and possible implications of chosen scheduling approach); Pierre Sauvé, Assessing the General Agreement on Trade in Services-Half-Full or Half-Empty?, 29 (4) J. WORLD TRADE $125,125-45$ (1995) (assessing the structure, key provisions, and practical implications of the GATS).

80 NAFTA, supra note 3, art. 1106.

81 Id. art. 1106(f).

82 Id. art. 1106(3). The four performance requirements which cannot be linked to the use of incentives are domestic content (art. 1106(3)(a)); domestic purchase requirements or preferences (art. 1106(3)(b)); relationship between imports and exports to foreign exchange inflows (art. 1106(3)(c)); and relationships of domestic sales to exports or foreign earnings (art. 1106(3)(d)).

83 The content of international rules governing expropriation has historically been characterized by competing positions between developed and developing 
protection provisions have been accepted by developing host states for several decades in BITs, although those states have resisted their incorporation into multilateral instruments. ${ }^{84}$

However, since the 1980s, there has been a dramatic reduction in incidences of direct expropriation of foreign investment. 85 Despite this lessening of expropriatory behavior, the NAFTA incorporates extremely strong guarantees of investment protection in Article 1110(1):

No Party may directly or indirectly nationalize or expropriate an investment of an investor of another Party in its territory or take a measure tantamount to nationalization or expropriation of such an investment ("expropriation"), except: for a public purpose; on a non-discriminatory basis; in accordance with due process of law and Article 1105(1); and on payment of compensation in accordance with paragraphs 2 through 6.86 .

Article 1110 clearly provides an obligation to compensate in the event of direct expropriation of an investment in a NAFTA state. But host states can always impose other regulatory measures that may incrementally impact an investor but are not as immediately serious as expropriation. The words "tantamount to nationaliza-

states. Developed states have generally insisted on specific requirements before an expropriation would be regarded as lawful in international law. These have typically been that the expropriation is in the public interest, not discriminatory and accompanied by full compensation. Developed states have insisted that the quantum of compensation, in turn, should reflect the so-called Hull formula of "prompt adequate and effective compensation." In contrast, until relatively recently, developing states have asserted that the question of expropriation is subject to the exclusive jurisdiction of the host country which determines how and to what extent compensation is to be paid. This approach was often motivated by ideology, especially in the former socialist states of Eastern Europe that held to the Marxist philosophy that nationalization did not require any payment of compensation. For a history of the development of the Hull formula and a comparison of the approach of developed and developing states to the question of compensation for expropriation, see M. SORNARAJAH, THE INTERNATIONAL LAW ON FOREIGN INVESTMENT 357-414 (1994).

84 See generally Andrew T. Guzman, Why LDCs Sign Treaties That Hurt Them: Explaining the Popularity of Bilateral Investment Treaties, 38 VA. J. INT'L L. 639 (1998) (analyzing the factors behind the agreement of developing countries to agree to strong provisions on investment protection in BITs).

85 See discussion supra Section 2.2. and text accompanying note 26.

86 NAFTA, supra note 3 , art. 1110(1). 
tion" in Article 1110 are clearly intended to deal with this type of progressive or indirect expropriation. The critical problem that has arisen with Article 1110 is that there is no clear definition of what will constitute an indirect expropriation. ${ }^{87}$ There is no guidance within NAFTA as to when legitimate governmental regulation, which in some way adversely impacts a foreign investor, constitutes indirect expropriation. This has led to a number of arbitral cases under Chapter 11 brought by investors arguing that seemingly normal regulatory measures are "tantamount to nationalization." 88 The flaw in the drafting of these clauses was also replicated in the MAI negotiating draft and stringently opposed by NGOs in their campaign against the MAI. ${ }^{89}$

Article 1110 is also not the only provision in NAFTA, which provides investors with guarantees of investment protection. Article 1105 provides investors with a minimum standard of treatment "in accordance with international law, including fair and equitable treatment and full protection and security." 90 This approach sets a minimum ceiling by which to treat foreign investors. In other words, even if a NAFTA host state treats foreign and domestic investors equally under its domestic law, it may still breach Article 1105 if an arbitral tribunal finds that the actual level of treatment violates international law standards of treatment. The problem is that there is little consensus on what this standard constitutes, and there is similar uncertainty as to the exact standard required by the phrases "fair and equitable treatment" and "full protection and security." 91 The problem is compounded by the fact that little guidance is given within the NAFTA text as to the interpretation of such general phraseology. The uncertainty in the scope of the application of Article 1105 has resulted in investors increasingly using this provision as an alternative means to Article 1110 in bringing arbitral cases to challenge regulatory measures imposed by NAFTA states. ${ }^{92}$

87 Id.

88 See infra Section 4.2. for an analysis of some of the main cases brought by investors under NAFTA Chapter 11.

89 See infra Section 5.3. for an analysis of the NGO campaign against the MAI.

90 NAFTA, supra note 3 , art. 1105.

91 See generally DOLZER \& STEVENS, supra note 2, at 58-61 (discussing similar provisions in BITs and acknowledging the lack of certainty in quantum of treatment provided by this type of clause).

${ }_{92}$ See also infra Section 4.2. (discussing case law stemming from NAFTA Chapter 11). 


\subsubsection{Dispute Settlement}

The fourth limb of the Chapter 11 model constitutes the procedures relating to the settlement of investment disputes. Under Section B of Chapter 11, an investor of a NAFTA state may commence arbitral proceeding for breach of any of the provisions in Section $A$ of Chapter 11.

There are strong normative justifications for the inclusion of an investor-state dispute resolution procedure in an agreement of this sort. Normally, disputes between a state and a private entity (rather than foreign government) would be subject to the jurisdiction of the host country. But in many developing host states, the legal system may not have the resources or judicial traditions to deliver certainty in the resolution of disputes. ${ }^{93}$ In addition (even for developed host states), once an investor has entered into the host state through a bricks-and-mortar-type of FDI, they are effectively a form of hostage to the host state that can extract rents through discriminatory conduct. With this form of relatively immobile investment, it is not normally a feasible option for investors to quit the host state in response. Direct dispute resolution procedures provide investors with a legitimate avenue by which to enforce commitments made by member states in the substantive component of the investment agreement.

This is an important point because there has been much criticism by NGOs and others of these dispute resolution procedures both in NAFTA and the draft MAI. However, the real concern about the breadth of some of the cases being brought by investors under NAFTA Chapter 11 should not be simply grounded in the existence of dispute resolution procedures. Instead, a more justifiable critique would focus on the broad and often undefined scope of the liberalization and protection commitments in the NAFTA model.

93 The tenor of investor concern with using the courts in developing states is evidenced by a recent statement from an investor in Cambodia:

The court system just doesn't work .... [W]e're seeing more business disputes being resolved in antagonistic and adversarial ways than ever .... Resolutions of disputes are lawless, it's law of the jungle .... [I]nvestors end up having to pay off judges, get some police involved and flail and push people to resolve even simple business disputes.

Phelim Kyne, Fear Grips Business in Cambodia, AGE (Melbourne, Austl.), July 22, 2000 , at 18. 


\subsubsection{Absences: Incentives and GATT Article XX-type Safety Valve}

Before examining the evolving jurisprudence from some of the NAFTA cases, it is worthwhile to briefly highlight two absences in the NAFTA model.

First, there are no direct substantive limitations on the use of investment incentives despite their clearly discriminatory purpose and distortive effect. There is, however, an interesting provision in Article 1114 that limits the ability of the NAFTA parties to lower their health, safety or environmental measures as an inducement for a foreign investor. The basis for this article is the fear that using this type of regulatory incentive to attract investors could lead to competitive downward pressure (or a race to the bottom) on regulatory standards. Interestingly, there appears to be little empirical justification for fears of a race to the bottom, at least on environmental standards. ${ }^{94}$ Yet, Article 1114 is notable from a normative perspective as integrating broader public values than simply economic liberalization goals. In the MAI episode, the OECD only belatedly considered similar provisions after sustained attacks by NGOs and growing public concern over the legitimacy of the agreement. Further, Article 1114 is not an overly ambitious mechanism for integrating broader values; it is an instrument of negative integration (in the sense of specifying what must not be done) rather than positive integration (which could, for example, set what environmental standards states must maintain).

Second, unlike the trade liberalization commitments in the GATT, 95 there is no Article XX-type ${ }^{96}$ safety valve in Chapter 11,

94 See David Vogel, Environmental Regulation and Economic Integration, in REGULATORY COMPETITION AND ECONOMIC INTEGRATION: COMPETING PERSPECTIVES 330-47 (Daniel C. Esty \& Damien Geradin eds., 2001) (arguing that there is a lack of empirical evidence indicating a race to the bottom on environmental standards).

95 Multilateral Agreements on Trade in Goods, Apr. 15, 1994, Agreement Establishing the World Trade Organization, Annex 1A, LEGAL INSTRUMENIS-RESULTS OF THE URUGUAY ROUND vol. 33, 33 I.L.M. 1154 (1994) [hereinafter GATT].

96 The General Agreement on Tariffs and Trade 1947, part II, art. XX, available at http://www.jurisint.org/pub/06/en/doc/05.htm. This article provides a number of exceptions from GATT obligations to enable member states to adopt measures designed to achieve certain non-trade goals. In part, Article $X X$ provides:

Subject to the requirement that such measures are not applied in a manner which would constitute a means of arbitrary or unjustifiable discrimination between countries where the same conditions prevail, or a 
which would provide a general exception to the prohibition against discrimination. But as will be seen next, there have been attempts in the evolving jurisprudence of the NAFTA cases to try and implant the kind of reasoning employed in the Article $X X$ cases of the GATT/WTO dispute resolution procedures. Inserting an Article XX-type exception-by arbitral fiat or otherwise-may not be the best way in which to counter the artificial use of investors of the Chapter 11 dispute resolution procedures. GATT panels themselves have struggled with the application of Article $X X$ and its constituent parts, which has led to a variety of inconsistent interpretations. ${ }^{97}$ These inconsistencies have in turn led to questions about the underlying legitimacy of the GATT and the capacity of GATT panels to manage complex tradeoffs between free trade and broader public values. ${ }^{98}$ From the perspective of a possible WTO

disguised restriction on international trade, nothing in this Agreement shall be construed to prevent the adoption or enforcement by any contracting party of measures:

-...

(b) necessary to protect human, animal or plant life or health; $\ldots$

(g) relating to the conservation of exhaustible natural resources if such measures are made effective in conjunction with restrictions on domestic production or consumption.

97 See, e.g., Report of the WTO Dispute Settlement Panel, European Communities Measures Affecting Asbestos and Asbestos-Containing Products, WT/DS135/R (Sept. 18, 2000) available at http://docsonline.wto.org/GEN_viewerwindow.asp ?D:/DDFDOCUMENTS/T/WT/DS/135R; Report of the WTO Appellate Body and Dispute Settlement Panel, United States-Standards for Reformulated and Conventional Gasoline, WT/DS2/AB/12 (May 20, 1996), available at http://docsonline.wto.org?GEN_viewerwindow.asp?D:/DDFDOCUMENTS/T /WT/DS/58RO; Report of the WTO Dispute Settlement Panel, United StatesImport Prohibition of Certain Shrimp and Shrimp Products, WT/DS58/R (Jan. 29, 1996), available at http://docsonline.wto.org/GEN_viewerwindow.asp?D: /DDFDOCUMENTS/T/WT/DS/58RO; Report of the WTO Dispute Settlement Panel, United States-Standards for Reformulated and Conventional Gasoline, WT/DS2/R (Jan. 29, 1996), available at http://docsonline.wto.org/GEN _viewerwindow.asp?D:/DOFDOCUMENTS/T/WT/DS/2R.W; Dispute Settlement Panel Report on United States Restrictions on Imports of Tuna, June 1992, vol. 33, 33 I.L.M. 839 (1994); Dispute Settlement Panel Report on United States Restrictions on Imports of Tuna, Aug. 16, 1991, 30 I.L.M 1594 (1991); Thailand Restrictions on Importation of and Internal Taxes on Cigarettes, Nov. 7, 1990, GATT B.I.S.D. (37th supp.), at 200 (1991).

98 Literature on the Article XX cases is voluminous. For thoughtful analyses of the difficulties in drawing the line between free trade goals and broader regulatory autonomy, see Robert Howse, Managing the Interface Between International Trade Law and the Regulatory State: What Lessons Should (and Should Not) Be Drawn 
investment agreement, this Article will consider an alternative approach. It will use the evolving NAFTA jurisprudence to illustrate the uncertain scope and conflicting interpretations of the substantive commitments in the NAFTA Chapter 11 model. In turn, the MAI simply replicated and extended many of these substantive commitments. It is submitted that WTO negotiators may be able to best balance the fine line between elimination of discriminatory measures whilst preserving core regulatory autonomy by carefully defining and delineating the substantive commitments within a WTO investment agreement (rather than relying on exceptions to otherwise undefined liberalization commitments).

\subsection{Some Problematic Chapter 11 NAFTA Case Law ${ }^{99}$}

The focus of this Section of the Article is on the evolving and inconsistent way in which arbitral tribunals have interpreted the broad liberalization and protection commitments in Chapter 11. For reasons of space, this Article will not consider all of the arbitral cases under Chapter 11.100 Instead, the Author has chosen three

from the Jurisprudence of the United States Dormant Commerce Clause, in REGULATORY BARRIERS AND THE PRINCIPLE OF NON-DISCRIMINATION IN WORLD TRADE LAW 139 (Thomas Cottier \& Petros C. Mavroidis eds., 2000); Michael Trebilcock \& Robert Howse, Trade Liberalization and Regulatory Diversity: Reconciling Competitive Markets with Competitive Politics, EUR. J. L. ECON. 5 (1998).

99 There is no central repository of documents submitted in Chapter 11 cases. For Chapter 11 cases involving Canada, the website of the Canadian Department of Foreign Affairs and International Trade (http://www.drait-maeci.gc.ca) maintains a comprehensive list of documents submitted in relation to such cases. For Chapter 11 cases involving other NAFTA states, the best source of documents are two websites maintained by attorneys who are active in this area: http://www.appletonlaw.com and http://www.toddweiler.com. These sites, however, are not complete, and some documents involved in NAFTA cases are difficult to locate.

100 For analyses that mainly focus on NAFTA Chapter 11 cases and particularly their impact on national environmental measures, see David A. Gantz, Potential Conflicts Between Investor Rights and Environmental Regulation Under NAFTA's Chapter 11, 33 GEO. WASH. INT'L L. REV. 651 (2001); J. Martin Wagner, International Investment, Expropriation and Environmental Protection, 29 GOLDEN GATE U. L. REV. 465 (1999). For a comparative overview of the NAFTA approach and other investment treaties on this question, see Thomas W. Wälde, International Disciplines on National Environmental Regulation: With Particular Focus on Multilateral Investment Treaties, in INTERNATIONAL INVESTMENTS AND PROTECTION OF THE ENVIRONMENT: THE ROLE OF DISPUTE RESOLUTION MECHANISMS 29, $64-70$ (Int'1 Bureau of the Permanent Court of Arbitration ed., 2001). See also Ari Afilalo, Constitutionalization Through the Back Door: A European Perspective on NAFTA's Investment Chapter, 34 N.Y.U. J. INI'L L. \& POL. 1 (2001) ("Argu[ing] that Chapter 11 threatens to establish a system of state liability for violations of key provisions of the gen- 
cases to illustrate trends towards inconsistent interpretation of Articles 1102 (National Treatment), 1105 (Minimum Standard of Treatment) and 1110 (Expropriation). Indeed, growing concern regarding the breadth of interpretation afforded to these provisions recently led the NAFTA Free Trade Commission to issue an interpretation to try and limit the operation of Chapter $11 .{ }^{101}$

\subsubsection{Metalclad Corporation v. United Mexican States}

In this case, Metalclad Corporation ("Metalclad"), a U.S. company, bought land in order to establish a waste disposal facility in the Mexican Municipality of Guadalcazar ("the Municipality") located in the Mexican State of San Luis Potosi ("State").102 In January 1993, Metalclad was granted a federal permit to construct a waste landfill, and construction started soon thereafter. However, the State government and the Municipality raised opposition based on environmental grounds. ${ }^{103}$ In October 1994, the Municipality ordered the cessation of building activities due to the absence of a municipal construction permit.104 Federal officials told Metalclad to apply for a municipal construction permit because it would be issued as a matter of course and would facilitate amicable relations with the Municipality. Metalclad applied for a permit, continued construction, and completed the landfill site in March 1995. But on December 1995, the Municipality denied Metalclad's application

eral trade in goods rules of NAFTA/WTO law."); David Lopez, Dispute Resolution Under NAFTA: Lessons from the Early Experience, 32 TEX. INT'L L.J. 163 (1997) (analyzing the formal dispute resolution mechanisms under NAFTA); Chris Tollefson, Games without Frontiers: Investor Claims and Citizen Submissions Under the NAFTA Regime, 27 YALE J. INT'L L. 141 (2002) (arguing that countries must recognize the asymmetry between how NAFTA parties perceive and respond to threats to their sovereignty in relation to transnational investors).

101 On July 31, 2001, the NAFTA states, through the auspices of the NAFTA Free Trade Commission, agreed to clarify the operation of some of the Chapter 11 provisions, particularly Article 1105 . See U.S., Canada, Mexico Agree to Clarify NAFTA's Investor-State Provisions, 19 (31) INSIDE U.S. TRADE 1, 21-23 (Aug. 3, 2001) [hereinafter NAFTA Free Trade Commission Interpretation]. Components of the Free Trade Commission Interpretation are examined further in Section 4.3 infra.

102 For a summary description of the facts in this dispute, see Abstract of ICSID (Additional Facility): Metalclad Corp. $v$ United Mexican States, vol. 40, 40 I.L.M. 35, paras. 28-69 (2001) [hereinafter Metalclad], available at http://www.dfeitmaeci .gc.ca/tna-mac/mun-metalclad-e.pdf.

103 Id. paras. 42-44.

104 Metalclad, supra note 102, para. 40. 
for a permit in a process that was closed to Metalclad. ${ }^{105}$ In September 1997, the Governor of the State issued an ecological decree declaring the site of the landfill a "Natural Area" for the protection of rare cactus. The State's decree further prevented the possibility of Metalclad's use of the waste operation facility.

Metalclad argued that Mexico, through the acts of its State and Municipal authorities, breached Articles 1105 (Minimum Standard of Treatment) and 1110 (Expropriation). The arbitral tribunal found in favor of Metalclad and awarded U.S. \$16.7 million in damages against Mexico in August 2000.106

First, the Tribunal found that Mexico breached its obligation to accord Metalclad "fair and equitable" treatment under Article 1105. The primary basis for this finding was the lack of "transparency" in the application processes for obtaining approval for the project at the various federal, state, and local levels.107 The Tribunal was also influenced by the fact that Metalclad's application for a local permit was denied without any notice or opportunity to appear at the hearing. ${ }^{108}$ Thus, the Tribunal in this case is interpreting the standard of treatment required by Article 1105 by reference to concepts of transparency and due process. The conclusion on transparency is particularly grounded by reference to the general transparency commitment in Article 102(1) of NAFTA. 109

The Tribunal also found that the actions of the Mexican authorities breached the prohibition on expropriation in Article 1110. In doing so, the Tribunal gave a very broad interpretation of the coverage of protection under Article 1110 as including:

$[\mathrm{N}]$ ot only open, deliberate and acknowledged takings of property... but also covert or incidental interference with the use of property which has the effect of depriving the

105 Metalclad was not notified of the Town Council meeting that considered the permit application nor was it given an opportunity to participate in that meeting. Metalclad's request for reconsideration of the denial of the permit was subsequently rejected. Id. para. 54.

106 Id. para. 59.

107 "The absence of a clear rule as to the requirement or not of a municipal construction permit, as well as the absence of any established practice or procedure as to the manner of handling applications for a municipal permit, amounts to a failure on the part of Mexico to ensure the transparency required by NAFTA." Id. para. 49.

108 Id. para. 49.

109 Id. para. 47. 
owner, in whole or in significant part, of the use or reasonably-to-be-expected economic benefit of property even if not necessarily to the obvious benefit of the host state. 110

On the facts, the Tribunal found that since the federal government approved the project, which was within its authority to do, and then permitted the Municipality to hinder the operation of the project, Mexico had taken a measure "tantamount to expropriation" in breach of Article 1110. Interestingly, the Tribunal went on to consider the effect of the ecological decree of the site as a "Natural Area." It basically concluded that this decree provided "further ground for a finding of expropriation" given its effect of barring the operation of the landfill.111 The breadth of the protection for indirect expropriation under Article 1110 can be gleaned from the Tribunal's view that "the implementation of the Ecological Decree would, in and of itself, constitute an act tantamount to expropriation."112

\subsubsection{S.D. Myers, Inc. v. Government of Canada}

In this case, S.D. Myers, a U.S. company, operated a Canadian entity to transport $\mathrm{PCB}$ hazardous waste from Canada to its treatment plants in Ohio. S.D. Myers claimed that Canada's banning of PCB exports from November 1995 to February 1997 breached Articles 1102 (National Treatment), 1105 (Minimum Standard of Treatment), 1106 (Performance Requirements), and 1110 (Expropriation). In November 2000, the arbitral Tribunal in this case found breaches of the first two claims but rejected the remainder of them.

In examining the national treatment obligation in Article 1102, the Tribunal held that it is necessary to take into account whether the measure is on its face discriminatory as well as discriminatory in effect.113 In other words, the Tribunal followed long-standing GATT/WTO jurisprudence in finding that national treatment (albeit in the investment context) extended to both de jure and de facto discrimination. The measure before the Tribunal was by no

110 Id. para. 50 (emphasis added).

111 Id. para. 51.

112 Id. (emphasis added).

113 North American Free Trade Agreement (NAFTA) Arbitration: S.D. Myers, Inc. v. Government of Canada, 40 I.L.M 1408, 1437 (2001) [hereinafter S.D. Myers]. 
means discriminatory on its face, as it was a blanket ban on all $\mathrm{PCB}$ exports (whether by domestic participants or foreign investors) out of Canada. The Tribunal, however, went on to indicate that the quantum of de facto discrimination necessary for grounds of a breach of the national treatment norm is whether the policy creates "a disproportionate benefit for nationals over non-nationals."114 This type of reasoning does not have an equivalent in the jurisprudence that has developed around the Article III national treatment norm of the GATT.115 Unfortunately, the Tribunal did not apply this approach to the facts. Instead, there is a troubling emphasis on the role of protectionist intent in grounding a breach of Article 1102.

Although the Tribunal states that protectionist intent is not alone sufficient to breach Article 1102,116 the structure of the judgment tends to contradict this statement. There is a lengthy analysis early in the judgment where the Tribunal reviews large amounts of evidence to find that the Canadian government passed the export ban as an attempt to protect domestic Canadian producers rather than basing it on environmental grounds. ${ }^{117}$ In contrast, there is little substantive analysis of the discriminatory impact of the export ban. At most, the Tribunal characterized the desire to retain the ability to process PCB waste in Canada as a legitimate goal but indicated that there were other ways in which Canada could have favored domestic PCB facilities without breaching NAFTA rules.118

This textual emphasis on intent in the judgment is problematic. In passing regulatory measures, governments often attempt to broaden public support for their policies by providing statements designed to appeal to vocal interest groups in the community. But these statements, by themselves, should not be enough to substan-

114 Id.

115 In fact, this point was raised in a later case initiated by Pope \& Talbot, Inc. against the Government of Canada. The Tribunal in that case rejected the application of the "disproportionate benefit" test to Article 1102. Pope \& Talbot, Inc. v. Canada, Trib. Arb. paras. 43-72 (Apr. 10, 2001), at http://www.dfait-maeci.gc .ca/tna-nac/award-merits-e.pdf.

116 S.D. Myers, supra note 113, at 1437.

117 Id. at 1424-48. The Tribunal also emphasizes the somewhat unfortunate words of the Canadian Minister of the Environment that it was Canada's policy that PCB waste should be disposed of "in Canada by Canadians." See id. at 1425 .

118 The two examples given are procurement preferences by Canadian governmental departments and the grant of subsidies to the Canadian industry. Id. at 1437. 
tiate an allegation of discrimination. Further, this kind of governmental intent analysis is problematic from a legitimacy perspective, whereby an arbitral Tribunal is seen as second-guessing the deliberations of a representative government. These concerns have long been expressed in prominent GATT/WTO cases analyzing the national treatment norm in Article III. ${ }^{119}$ It is suprising that the arbitrators in this case failed to heed these long-standing concerns.

In its analysis of Article 1105 (Minimum Standard of Treatment), the Tribunal's approach seems'somewhat contradictory to the strong emphasis on intent under Article 1102.120 The Tribunal goes on to consider that a breach of Article 1105 occurs only if an investor has been "treated in such an unjust or arbitrary manner that the treatment rises to the level that is unacceptable from the international perspective." 121 That treatment has to be "made in

119 See WTO Dispute Settlement Decisions Report of the Panel, Japan Taxes on Alcoholic Beverages, WT/DS8/R; WT/DS10/R; WT/DS11/R (July 11, 1996), para. 6.16, reprinted in 1 BERNAN'S ANN. REP. 69, 169-70 (1998)

The Panel also noted that very often there is a multiplicity of aims that are sought through enactment of legislation and it would be a difficult exercise to determine which aim or aims should be determinative ... Moreover, access to the complete legislative history ... could be difficult or even impossible for a complaining party to obtain. Even if the complete legislative history is available, it would be difficult to assess which kinds of legislative history (statements in legislation, in official legislative reports, by individual legislators, or in hearings by interested parties) should be primarily determinative of the aims of the legislation.

Id. See also WTO Dispute Settlement Decisions Report of the Appellate Body, Japan Taxes on Alcoholic Beverages, WT/DS8/AB/R; WT/DS10/AB/R; WT/DS11/AB/R (October 4, 1996), 196, reprinted in 1 BERNAN'S ANN. REP. 183 (1998) (emphasizing that "[t]he proper interpretation of the Article is, first of all, a textual interpretation"). But cf. WTO Dispute Settlement Decisions Report of the Appellate Body, Chile Taxes on Alcoholic Beverages, WT/DS/97/AB/R (Dec. 13, 1999), reprinted in 14 BERNAN'S ANN. REP. 49 (1998) (stressing the permissibility of taking into account the statutory purposes or objectives expressed in the design, architecture, and structure of the regulatory measure for the purpose of examining the issue "so as to afford protection" in the context of Article III.1 of GATT).

${ }_{120}$ S.D. Myers, supra note 113, at 1438 . When interpreting and applying the "minimum standard," a Chapter 11 tribunal does not have an open-ended mandate to second-guess government decision-making. Governments have to make many potentially controversial choices. In doing so, they may appear to have made mistakes, to have misjudged the facts, proceeded on the basis of a misguided economic or sociological theory, placed too much emphasis on some social values over others and adopted solutions that are ultimately ineffective or counterproductive. The ordinary remedy, if there were one, for errors by modern governments is through internal political and legal processes, including elections.

121 Id. 
light of the high measure of deference that international law generally extends to the right of domestic authorities to regulate matters within their own borders."122 But unlike Metalclad, with its emphasis on transparency and due process, little attention is given to exactly what this level of treatment should be to ground a breach of Article 1105. Instead, the Tribunal simply finds that "on the facts of this particular case the breach of Article 1102 essentially establishes a breach of Article 1105 as well."123 This seemingly simplistic approach of linking a breach of Article 1102 to a breach of Article 1105 underscores the uncertainty inherent in its application.

The Tribunal found no breach of Article 1110 on expropriation. Unlike Metalclad, the Tribunal appeared uncomfortable with extending protection from expropriation to the impact of normal regulatory measures. The Tribunal found that the term "expropriation" carries with it the connotation of a "taking" of personal property by a governmental authority with a view towards transferring ownership to another person. ${ }^{124}$ In fact, the Tribunal went so far as to conclude that regulatory conduct by public authorities is unlikely to be the subject of a legitimate complaint under Article 1110.125 The Tribunal found that the PCB ban did not amount to an "expropriation" because it was temporary and the evidence did not support a transfer of property or directly benefit others. ${ }^{126}$

122 Id.

123 Id.

124 Id. at 1440.

125 Id. The greater deference to regulatory autonomy is clearly evident in the following statement:

Expropriations tend to involve the deprivation of ownership rights, regulations, and lesser interference. The distinction between expropriation and regulation screens out most potential cases of complaints concerning economic intervention by a state and reduces the risk that governments will be subject to claims as they go about their business of managing public affairs. An expropriation usually amounts to a lasting removal of the ability of an owner to make use of its economic rights although it may be that, in some context and circumstances, it would be appropriate to view a deprivation as amounting to an expropriation, even if it were partial or temporary.

Id.

126 Id. 
Finally, a notable aspect of this arbitral decision is the fact that a separate opinion was prepared by one of the arbitrators. ${ }^{127}$ Within this lengthy opinion, the arbitrator addresses the tension between regulatory autonomy and the liberalization and protection provisions of NAFTA. In particular, the arbitrator argues that the analysis employed to determine whether there has been a breach of Article 1102 (National Treatment) may be similar to that used in an Article XX case under GATT/WTO auspices. ${ }^{128}$ The intention of the arbitrator on this point is laudable: to use the reference to "in like circumstances" in Article 1102 as a meaningful way for respondent governments to justify legitimate regulatory measures with limited effects on free trade and investment goals. ${ }^{129}$ But the problem with this approach is that it grafts an exception model (such as Article XX in the GATT) to Chapter 11 as a means of resolving this question. Within GATT/WTO jurisprudence, the Article $X X$ exception has been interpreted in a variety of inconsistent ways. In particular, the analysis of whether a given measure is the least trade-restrictive measure available to achieve a non-free trade goal (such as the protection of public health) has led to the curious,

127 The separate opinion was prepared by Dr. Bryan Schwartz and concurs with most of the findings in the arbitral award but provides some additional reasoning. Id. at 1447-89.

128 The arbitrator states:

Article 1102 (National Treatment) of NAFTA is not made subject to an equivalent of Article $X X$ (General Exceptions) of GATT. Read in its proper context, however, the phrase 'like circumstances' in Article 1102 in many cases does require the same kind of analysis as is required in $\mathrm{Ar}$ ticle $X X$ cases under the GATT. The determination of whether there is a denial of national treatment to investors or investments 'in like circumstances' under Article 1102 of NAFTA may require an examination of whether a government treated non-nationals differently in order to achieve a legitimate policy objective that could not be reasonably accomplished by other means that are less restrictive to open trade.

Id. at 1454 .

129 In comparison, the other members of the arbitral tribunal take a much more restricted view of the operation of the words "in like circumstances" in Article 1102. Initially, the members find that the interpretation of this phrase must take into account general principles that emerge from the legal context of the NAFTA, including its environmental provisions. They go on to say that this assessment "must also take into account circumstances that would justify governmental regulations that treat them differently in order to protect the public interest." However, these broad interpretative principles are not applied to the facts of the case. Instead, the Panel members focus largely on whether the foreign investor complaining of discrimination is in the same economic or business sector as that of the domestic participant in the market. Id. at 1437. 
and potentially dangerous situation of some GATT Panels ignoring the realities of the regulatory decision-making process. ${ }^{130}$

\subsubsection{Methanex v. United States}

In this on-going action, Methanex, a Canadian company, with some facilities located in the United States, has brought a Chapter 11 action against an Executive Order in which the State of California provided for the removal of a gasoline additive known as MTBE by no later than December 31, 2002.131 The basis for the decision to ban MTBE was a study undertaken by the University of California, which concluded that, "there [were] significant risks and costs associated with water contamination due to the use of MTBE." 132 Methanex claims to be one of the world's largest producers and marketers of methanol, a principal ingredient of MTBE. 133

Methanex originally brought an action under Chapter 11 on the basis that the California measure breached Articles 1105 (Minimum Standard of Treatment) and 1110 (Expropriation) and claimed

130 In particular, see Thailand-Restrictions on Importation of and Internal Taxes on Cigarettes, Nov. 7, 1990, GATT B.I.S.D. (37th Supp.) at 200 (1991) (summarizing GATT's analysis of Thailand's cigarette tax structure and importation policies). In this case, Thailand attempted to defend import restrictions and discriminatory tax treatment imposed against American cigarettes as "necessary" for public health reasons under Article $X X(b)$. Thailand had adopted a variety of measures to achieve its public health objectives including advertising bans, health warnings on cigarette packets, and discriminatory measures. Thailand justified the discriminatory measures on the basis of evidence put forward by the World Health Organization that the U.S. cigarette industry had the resources to avoid non-inconsistent measures such as advertising bans. The Panel simply ignored this evidence in finding that least-restrictive alternatives such as advertising bans were adequate to meet Thailand's public health objectives.

131 For a summary description of the facts in the case, compare Claimant Methanex Corporation's Draft Amended Claim, Methanex Corp. v. United States, (Feb. 12, 2001), at 4-33, [hereinafter Methanex Amended Claim] (alleging that the ban is a result of "the action of the U.S. ethanol industry and its political allies to expand ethanol's protected status, and in particular their attempts to create a public perception that MTBE and methanol are dangerous foreign products whose use should be restricted"), available at http://www.toddweiler.com (law modified Sept. 26, 2002) with Statement of Defense of Respondent United States, Methanex Corp. v. The United States of America, (Aug. 10, 2000), at 6-26 [hereinafter U.S. Defense] (stating that "the California legislature's authorization of funding for anniversary study of the public health and environmental effects of MTBE" is a violation of NAFTA), available at http://www.toddweiler.com.

132 U.S. Defense, supra note 131, at 18-22.

133 See Methanex Amended Claim, supra note 131, at 4-5 ("Methanex's sales represented approximately $24 \%$ of the world market in methanol."). 
damages of U.S. $\$ 970$ million. The United States vigorously opposed this claim with a particular emphasis on its impact on the regulatory autonomy of the NAFTA states. ${ }^{134}$ On February 12, 2001, Methanex lodged an amended claim that builds on some of the worrying trends discerned in earlier NAFTA cases, especially S.D. Myers. In August 2002, an arbitral tribunal ruled on the U.S. challenge to Methanex's claim on jurisdictional grounds. ${ }^{135}$ The Tribunal found that Methanex's amended claim as a whole did not meet the jurisdictional requirements of Article 1101 but it ruled that certain Methanex claims might fall within the jurisdiction of the Tribunal. ${ }^{136}$ It then ordered Methanex to submit a fresh pleading in the case supported by sufficient evidentiary materials. ${ }^{137}$

As of the date of the writing of this Article, the revised Methanex claim had not been submitted. Yet, the original points put forward in the amended claim are clearly instructive in the way that they have been influenced by trends from previous decisions of NAFTA arbitral tribunals. First, the amended claim argues that the California measure breaches Article 1102 (National Treatment). In raising its argument, the amended claim relies heavily on the analysis of the national treatment norm in S.D. Myers. ${ }^{138}$ As in S.D. Myers, Methanex attempts to ground its case for breach of Article 1102 by adducing evidence of a protectionist intent or pur-

134 The tenor of the U.S. defense is evident in the following extract:

Methanex's claim does not remotely resemble the type of grievance for which the States Parties to the NAFTA created the investor-state dispute resolution mechanism of Chapter 11. Methanex's case is founded on the proposition that, whenever a State takes action to protect the public health or environment, the State is responsible for damages to every business enterprise claiming a resultant setback in its fortunes ... Plainly put, this proposition is absurd. If accepted by the Tribunal, no NAFTA Party could carry out its most fundamental governmental functions unless it were prepared to pay for each and every economic impact occasioned by doing so. The NAFTA Parties never intended the NAFTA to bring about such a radical change in the way that they function, and Methanex cannot show otherwise.

U.S. Defense, supra note 131 , at 2.

135 See Methanex Corporation v. United States, 1st Partial Award, Aug. 7, 2002 (explicating the arbitral tribunal's findings), available at http://www.state .gov/documents/organization/12613.pdf.

136 Id. at 83-84.

137 Id. at 84.

138 Methanex Amended Claim, supra note 131, at 45-47 (quoting from S.D. Myers the factors for determining whether measure is contrary to natural treatment norm). 
pose within the California measures. The protectionist purpose is framed as a desire to prefer California's ethanol industry as a substitute product for MTBE.139 Yet, the evidence adduced is not nearly as strong as that provided for in S.D. Myers. For example, this part of the claim relies on relatively innocuous statements within the Executive Order suggesting further analysis on fostering a domestic ethanol industry and labeling requirements at the pump that the gasoline does not contain MTBE.140 In contrast, here, there is no attempt to prove the discriminatory impact of the California measure.

Methanex's revised argument on the basis of Article 1105 (Minimum Standard of Treatment) is of even greater concern. Methanex attempts to define the scope of operation of Article 1105, but does so in an extremely broad manner. Methanex makes the preliminary point that the reference to "international law" in Article 1105 includes both customary and treaty-based forms of international law. ${ }^{141}$ The reference to treaty-based forms of international law is then used to try to bring in certain GATT/WTO disciplines within the coverage of Article 1105. This represents a logical link to the approach taken in S.D. Myers particularly in the separate opinion on Article 1102. On the whole, Methanex argues that Article 1105 covers a minimum of four separate principles. ${ }^{142}$

On the first purported principle, Methanex attempts to argue that the decision to ban MTBE was unfair because of alleged campaign contributions provided to the California governor by a leading U.S.-based ethanol producer. ${ }^{143}$ In other words, Methanex is using the largely undefined principles inherent in Article 1105 to impugn the process of domestic rule-making, rather than its effects on a foreign investor. The third purported principle follows the curious (and seemingly simplistic) S.D. Myers approach of finding a breach of Article 1102 (National Treatment) as sufficient in itself as grounds for breach of Article 1105. The fourth purported prin-

139 Id. at 47.

140 Id.

141 Id. at 48.

142 These are: (i) that a decision maker purportedly acting independently and in the public interest must not be biased by pecuniary considerations; (ii) that state officials must act reasonably and in good faith; (iii) that discriminatory measures are not allowed; and (iv) that a regulatory measure taken by a state must not be a disguised form of protection but instead must be the least traderestrictive of the reasonably alternative measures. Id. at 49-58.

143 Id. at 49-51. 
ciple also runs along the lines of S.D. Myers, arguing that Article 1105 includes treaty-based forms of international law. ${ }^{144}$ Methanex uses this preliminary point to structure an argument based on the WTO Agreement on Technical Barriers to Trade and Agreement on the Application of Sanitary and Phytosanitary Measures. The essence of these arguments is that the use of a "least restrictive means" analysis to suggest that the California ban on MBTE violated these agreements because there were less restrictive means of solving the problem of contamination of drinking water, such as fixing leaking storage tanks. ${ }^{145}$ Thus, Methanex is using the opening made in S.D. Myers to argue that the approach of specific exceptions to the free trade goals inherent within the GATT/WTO framework applies to the Chapter 11 NAFTA model. Methanex then also, somewhat cynically, uses that exception approach to argue that the California measures do not satisfy the conditions necessary in which to justify an exception to the NAFTA commitments.

Finally, Methanex's claim that the California measure constitutes an expropriation under Article 1110 also seems to be artificially stretched. The basis of the expropriation is a claim for loss of business or profits rather than an outright "taking" of an investment. ${ }^{146}$ Aside from the debatable proposition that these are interests that can be expropriated under Article 1110, there is also the

144 The influence of the separate opinion in S.D. Myers is apparent throughout Methanex's amended claim. For example:

As Dr. Bryan Schwartz stated in his S.D. Myers separate opinion: "The interpretation and application of Article 1105 must, I tend to think, also take into account the letter or spirit of widely, though not universally, accepted international agreements like those in the WTO system and those typical of BITs."

Id. at 58 .

145 Id.

The principle of international law most applicable in this case is the widely-accepted WTO/GATT rule that regulatory measures are only acceptable if they meet certain conditions. Such measures are legal if: (1) they are intended to achieve a legitimate objective, (2) they are the least trade-restrictive alternative that can achieve the legitimate objective, and (3) they do not constitute a disguised restriction on international trade. These requirements are found in at least two multilateral treaties (1) the WTO Agreement on Technical Barriers to Trade ... and (2) the WTO Agreement on Sanitary and Phytosanitary Measures ....

146 Id. at 69-70. 
problem that Methanex is claiming an expropriation even though the ban on MTBE will only take effect in 2003.

\subsection{A Limited Retreat: The NAFTA Free Trade Commission Interpretation}

The submissions put forward in Methanex represent a very aggressive and broad interpretation of the Chapter 11 commitments. But they are partly based on broad and sometimes conflicting interpretations by past NAFTA tribunals. Concern as to the breadth of these approaches has led the NAFTA states to actively consider ways in which to limit the scope of the protections offered by Chapter 11. Canada has long been an advocate for clarifications to Chapter 11 but, until Methanex, the United States had not been as supportive of such an approach. ${ }^{147}$ In fact, since the end of the Clinton administration, there had been an "inter-agency" deadlock on the question of investment protections in future trade deals. The U.S. Environmental Protection Authority, Interior Department, and Justice Department have all favored scaling back the investment protections, but have faced opposition by the U.S. Trade Representative and the Departments of Commerce and the Treasury. ${ }^{148}$

On July 31, 2001, the NAFTA states agreed, through the auspices of the NAFTA Free Trade Commission ("FTC"), to clarify the operation of some of the Chapter 11 provisions. ${ }^{149}$ Of most interest for the purposes of this discussion is the interpretation relating to Article 1105. First, the interpretation issued by the FTC limits the operation of Article 1105 to require member states only to provide "the customary international law minimum standard of treatment of aliens." 150 Unfortunately, the FTC interpretation goes no further to provide guidance on exactly what this standard constitutes. But the obvious intent is to deal with the tendency in some of the

147 Compare Zoellick Cool to Restrictions on Investor State Disputes, 19 (16) INSIDE U.S. TRADE 5, 6 (Apr. 20, 2001) [hereinafter Zoellick] (discussing the resistance of the U.S. Trade Representative to the Canadian push for limits on the Chapter 11 model), with U.S. Cites NAFTA Party Agreement to Limit Investor-State Disputes, 19 (20) INSIDE U.S. TRADE 11, 12 (May 18, 2001) (noting U.S. concerns about the breadth of the Methanex claims under Chapter 11).

148 Zoellick, supra note 147 , at 12.

149 A copy of the interpretation can be obtained from the web site of the Canadian Department of Foreign Affairs and International Trade, available at http://www.dfait-maeci.gc.ca. See NAFTA Free Trade Commission Interpretation, supra note 101 (providing a brief analysis of the interpretation).

150 Id. at 21. 
Chapter 11 cases (especially in S.D. Myers) to introduce principles from treaty-based forms of international law, particularly from the GATT/WTO agreements. The FTC interpretation also attempts to deal with the S.D. Myers approach to Article 1105 by finding that "a determination that there has been a breach of another provision of the NAFTA, or of a separate international agreement, does not establish that there has been a breach of Article 1105(1)."151 Canada also sought restrictions on the ways in which a Chapter 11 panel could approach the question of expropriation under Article 1110,152 however the interpretation is silent on this point, and it is unclear whether the United States and Mexico favor this approach. ${ }^{153}$ There is also no guidance on what will potentially be the most difficult issue for future Chapter 11 panels: developing a test to apply the national treatment norm in the investment context without unduly impinging on host state regulatory freedoms.

Unfortunately, this is not the end of the story. In January 2002, Methanex challenged the ability of the parties to limit the operation of Chapter 11 in this manner. ${ }^{154}$ To support its claims, Methanex submitted an affidavit from a former Mexican negotiator stating that the negotiating history of Chapter 11 contradicts the interpretation adopted by the FTC. ${ }^{155}$ In any event, Methanex's case has recently suffered a new blow with a proposal before the U.S. Senate for a national ban on the use of MTBE as an oxygenate in gasoline. 156 However, the ongoing uncertainty as to the breadth of the Chapter 11 provisions has forestalled finalizing the investment provisions in future initiatives, particularly proposed free trade agreements with Singapore and Chile as well as the regional Free Trade Area of the Americas initiative. ${ }^{157}$

151 Id. at 22.

152 Id.

153 Id.

154 Methanex Questions New Limits on NAFTA Investor Protections, 20 (1) INSIDE U.S. TRADE 1, 22-25 (Jan. 4, 2002).

155 Id. at 23-25.

156 See David E. Rosenbaum, With Alaska Exploration Rejected, Senate Looks to Ethanol, N.Y. TMME, Apr. 23, 2002, at A16 (discussing the politics of ethanol).

157 See Administration Mulls Government Veto Option for Investor Disputes, 20 (11) INSIDE U.S. TRADE 1, 22-23 (Mar. 15, 2002); Business, Environmentalists Clash over TPA Investor Protections, 19 (42) INSIDE U.S. TRADE 9, 10 (Oct. 19, 2001); Group Faces Decision on Investor Protections for Chile FTA, 19 (47) INSIDE U.S. TRADE 1, 1820 (Nov. 23, 2001); House Democrats Seek New Limits to Investor-State Disputes, 19 (40), INSIDE U.S. TRADE 1, $22-23$ (Oct. 5, 2001); Investment Remains a Hole in U.S.Singapore FTA Negotiations, 19 (35) INSIDE U.S. TRADE 5, 6 (Aug. 31, 2001); U.S. In- 
The next Section of the Article will consider the failed negotiations within the OECD towards the MAI. Although most (but not all) of the NAFTA case law post-dates the MAI negotiations, the MAI provisions themselves largely replicated the NAFTA Chapter 11 model. It was only towards the end of the failed negotiations that the negotiators recognized some of the problems inherent in this model and made a belated attempt to rectify them.

\section{THE MAI EPISODE: A CAUTIONARY TALE}

\subsection{Overview}

In 1991, the OECD commenced work on the idea of a multilateral agreement on investment. 158 The decision to study the possibility of such an agreement was driven by three factors examined earlier in Section 2 of this Article: the rapid growth in investment flows by the early 1990s, the trend towards unilateral liberalization of national restrictions on foreign investment in both developed and developing states, and the patchwork of investment instruments at the international level.159

The results of the technical analysis were presented as a report to the OECD Council of Ministers in May 1995.160 Based on this report, the OECD Council agreed to commence negotiations towards MAI with the mandate that the agreement was to:

provide for a broad multilateral agreement for international investment with high standards for the liberalization of investment regimes and investment protection with effective dispute settlement procedures; [and] be a free-standing in-

dustry Pushes NAFTA Investment Model in Future Agreements, 19 (17) INSIDE U.S. TRADE 1, 22 (Apr. 27, 2001); Zoellick Warns Against Changes to Investor-State Provision, 19 (43) INSIDE U.S. TRADE 19, 20 (Oct. 26, 2001).

158 OECD, A MULTILATERAL AGREEMENT ON INVESTMENT: REPORT BY THE COMMITTEE ON INTERNATIONAL INVESTMENT AND MULTINATIONAL ENTERPRISES (CIME) AND THE COMMITTEE ON CAPITAL MOVEMENTS AND INVISIBLE TRANSACTIONS (CMIT), 1995 DAFFE/CMIT/CIME(95)13/FINAL, Annex [hereinafter CIME/CMIT REPORT]. On February 19, 2002, the OECD publicly released a large quantity of documents relating to the MAI negotiations (including the last version of the draft negotiating text on its website), available at http://www.oecd.org /daf/mai.

159 See generally CIME/CMIT REPORT, supra note 158, $\$ 1$ (discussing each of these factors in The Case for a Multilateral Agreement on Investment).

$160 \mathrm{Id}$. 
ternational treaty open to all OECD Members and the European Communities and to accession by non-OECD Member countries, which will be consulted as negotiations progress. 161

The first part of the mandate highlights the relatively limited scope of the MAI exercise. Its primary aim was to build upon existing OECD instruments to set "high standards" on established norms of investment liberalization and protection backed up by an effective process of dispute settlement. ${ }^{162}$ Thus, the conception of the MAI was based along the lines of the NAFTA Chapter 11 model of an investment agreement. The United States was also strongly in favor of having the OECD as the forum for the MAI negotiations. ${ }^{163}$ The basis for the U.S. preference for the OECD appears to be linked to the relatively modest results of the Uruguay Round TRIMS Agreement which was often attributed to the recalcitrance of developing states. 164 The MAI was intended to avoid this problem by negotiating strong, comprehensive rules amongst the supposedly like-minded developed countries of the OECD.165

The view of the MAI at its inception in 1995 as an uncontroversial, somewhat technical exercise of building upon existing norms

161 Id. $\$ 3$ [Mandate].

162 See id. $\$ 2$ (discussing the aims of the negotiations in Features of a Multilateral Agreement on Investment).

163 The role of the United States in spearheading negotiations within the OECD is examined in Elizabeth Smythe, Your Place or Mine? States, International Organizations and the Negotiation of Investment Rules, 7 (3) TRANSNAT'L CORP. 85, 101 (1998). The author bases her various assertions, in part, on interviews conducted with MAI negotiators.

164 TREBILCOCK \& HowSE, supra note 46 , at 358.

165 During the negotiations towards the MAI from 1995 to 1998, there were 29 member states of the OECD. These were Australia, Austria, Belgium, Canada, the Czech Republic, Denmark, Finland, France, Germany, Greece, Hungary, Iceland, Ireland, Italy, Japan, the Republic of Korea, Luxembourg, Mexico, Poland, the Netherlands, New Zealand, Norway, Portugal, Spain, Sweden, Switzerland, Turkey, the United Kingdom, and the United States of America. The OECD also identified certain countries as likely candidates for accession and invited them to sit in as observers at the negotiations in 1997 and 1998. These were initially Argentina, Brazil, Chile, Hong Kong, China, and the Slovak Republic. The three Baltic countries-Estonia, Latvia, and Lithuania-were also later invited to join as observers. See OECD, MULITLATERAL AgREEMENT ON INVESTMENT: REPORT BY THE CHAIRMAN OF THE NEGOTIATING GROUP, Apr. 20, 1998, DAFFE/MAI(98)9/FINAL, at 3 (listing the non-Member countries), available at http://www.oecd.org /daf/mai. 
is also reflected in the time assigned for the conclusion of negotiations. The report set an objective of two years for the conclusion of negotiations, in time for the meeting of the OECD Council of Ministers in 1997.166 This two-year time frame for the conclusion of negotiations proved overly ambitious. 167 Two problem areas soon arose. The first was internal as the political commitment of the OECD member states to the liberalization commitments within the MAI began to erode. Ongoing disputes between the United States, Canada and the European Union ("EU") member states began to overshadow the negotiations. ${ }^{168}$ The MAI negotiators found it impossible to resolve three particular issues: the extra-territorial impact of the U.S. Helms-Burton Act; 169 the desire of France and Can-

166 CIME/CMIT REPORT, supra note 158, § 3 [Mandate].

167 Aside from the delays, which developed within the MAI negotiations, history has shown that negotiations towards multilateral investment instruments proceed slowly, if at all. Within the WTO, negotiations towards the TRIMS Agreement (which deals with performance requirements) were only concluded after what has been described as "five years of tough negotiations." JOHN CROOME, RESHAPING THE WORLD TRADING SYSTEM: A History OF THE URUGUAY ROUND 309 (1995).

168 For further analysis of these so-called "deal breakers," see Peter T. Muchlinski, The Rise and Fall of the Multilateral Agreement on Investment: Lessons for the Regulation of International Business, in FOUNDATIONS AND PERSPECTIVES OF INTERNATIONAL TRADE LAW 114, 129-31 (Ian Fletcher et al. eds., 2001).

169 In the middle of the MAI negotiations in March 1996, the Cuban Liberty and Democratic Solidarity Act (Helms-Burton Act) entered into law in the United States. Title III of the Act allows U.S. citizens and corporations whose property was expropriated by the Cuban government any time after January 1, 1959 to sue for damages against anyone who "traffics" in their former property after November 1, 1996. Title IV prohibits entry into the United States by persons who "traffic" in confiscated property after March 12, 1996. This Act led to a fierce policy conflict between the United States, EU, and Canada in the middle of the MAI negotiations. The underlying problem was that the Helms-Burton Act potentially operated both extraterritorially and in a discriminatory manner against foreign investors from non-U.S. states operating in Cuba. After the filing of a complaint by the EU against the United States over the Helms-Burton Act in the WTO, an understanding was eventually reached on this issue between the United States and EU in May 1998 (but with significant restrictions on its scope which also envisaged amendments to the MAI negotiating text). But by that time, the Lalumière Commission had already begun its investigation into the MAI leading to France's withdrawal from negotiations in October 1998. It is notable that the conflict over the Helms-Burton Act overshadowed the MAI episode from early in the negotiations (in 1996) right up until 1998. See generally the Cuban Liberty and Democratic Solidarity Act, 1996 U.S. Public Law 104-14, Mar. 12, 1996, vol. 35, 35 I.L.M. 357 (1996); EDWARD M. GRAHAM, FIGHTING THE WRONG ENEMY: ANTIGLOBAL ACTIVISTS AND MULTINATIONAL ENTERPRISES 28 (2000); European Union-United States, Understanding with Respect to Disciplines for the Strengthening of Investment 
ada (opposed by the United States) to include a general exemption for culture in the MAI; $; 70$ and the EU proposal for an exemption for regional economic organizations. ${ }^{171}$ The second problem was the onset of an aggressive campaign by non-governmental organizations ("NGOs") opposing the MAI in early 1997. A striking feature of the structure of this campaign was the use of the Internet to coordinate and link up a vast array of NGOs opposed to the MAI. At the height of the NGO campaign, there were an estimated fifty websites devoted to the MAI, together with 200 newsgroup postings. ${ }^{172}$ Aside from general concerns about economic globalization, the NGOs also opposed the MAI because of a substantive critique of the similarities between the MAI provisions and the NAFTA Chapter 11 model.

These difficulties caused the negotiations to outrun the original two-year completion date. At the OECD Ministerial Council meeting in May 1997, the Ministers agreed to extend the completion date of negotiations to the May 1998 Ministerial meeting. But by 1998, the political climate, which had led the OECD to commence MAI negotiations had dramatically changed. By that year, the world witnessed in Southeast Asia "the strongest financial panic

Protection (May 19, 1998), at http://www.europa.eu/int/news/summit /Summit9805/invest.htm.

170 The proposed exception would preserve the right of a Contracting Party from taking any measure to regulate investment of foreign companies and the conditions of activity of these companies, in the framework of policies designed to preserve and promote cultural and linguistic diversity. This proposal was strongly opposed by U.S. entertainment and media interests (the second largest U.S. export industry). See OECD, ThE MAI NegotiatING TEXT, Final Version, Apr. 24, 1998, DAFFE/MAI(98)7/REV1, at 128 [hereinafter MAI NEGOTIATING TEXT] (setting out a proposed exception clause for cultural industries). See also William Dymond, The MAI: $A$ Sad and Melancholy Tale, in CANADA AMONG NATIONS 35 (Carleton University 1999) (discussing American opposition).

171 This proposal exempted defined regional economic organizations from the most-favored-nation obligation under the MAI. This clause was strongly opposed by the United States, which argued that exemptions from the most-favored nation (MFN) standard should only be permitted as listed country-specific exceptions. MAI Negotiating Text, supra note 170, at 118-19; UNCTAD, LESSONS FROM THE MAI14-15 (1999).

172 Stephen Kobrin, The MAI and the Clash of Globalizations, 112 FOREIGN POL'Y 97, 97 (1998). See also Madelaine Drohan, How the Net Killed the MAI, GLOBE \& MaIL (Toronto), Apr. 29, 1998, at 14; Guy de Jonquières, Network Guerillas, FIN. TIMES, Apr. 30, 1998, at 12. 
since the Great Depression."173 The currency crisis affecting the Thai baht in July 1997 led to a dramatic drop in loan finance and portfolio investment into Indonesia, Korea, Malaysia and to some extent the Philippines over the course of $1998 . .^{174}$ Comparatively, FDI flows proved to be relatively stable. 175 In September 1998, Malaysia imposed controls on some capital outflows in response to the crisis. ${ }^{176}$ Two weeks prior to the Malaysia announcement, Russia had not only imposed controls on capital outflows but had also defaulted on its loan obligations by announcing a 90 -day moratorium. ${ }^{177}$

Against these dramatic changes in the global economy, the prospects for the MAI as a treaty which aimed to liberalize all forms of capital flow looked less certain. ${ }^{178}$ The new and less favorable atmosphere was reflected in the April 1998 OECD Ministerial meeting. Contrary to past practice, the MAI became the single focus for discussion in the meeting. ${ }^{179}$ Ministers reaffirmed "the importance they attach to achieving a comprehensive framework for investment" but went on to announce "a period of assessment and further consultation between the negotiating parties and with interested parts of their societies" in preparation for the next meeting of the negotiators in October 1998. ${ }^{180}$

173 Helmut Reisen, AfTer the GREat Asian Slump: TOWARds a COHERENT Approach to Global CaPITAL Flows 5 (OECD Development Centre, Policy Brief No. 16, 1999).

174 Id. at 9.

175 See generally WTO, ANNUAL REPORT 1999 8, 28-30 (1999); FOREIGN DIRECT INVESTMENT, supra note 31, at 161-62; WORLD INVESTMENT REPORT 2000, supra note 17, at 17-23 (detailing statistical evidence of the stability of FDI in terms of outflows when compared to other forms of capital in the period following the Asian financial crisis).

176 These measures were aimed primarily at short-term capital flows such as portfolio investment undertaken by hedge funds and other institutional investors. The restrictions explicitly excluded FDI which was something that the Malaysian authorities were at pains to publicize. See Press Release, IMF \& World Bank Group, Statement by Dato Mustapa Mohamed, Second Finance Minister of Malaysia, No. 45 (October 6-8 1998).

177 Reisen, supra note 173, at 21.

178 The MAI definition of "investment" was even broader than that adopted in NAFTA Chapter 11. See infra Section 5.2.1.

179 DAVID HENDERSON, THE MAI: A STORY AND ITS LESSONS 42 (1999).

180 William H. Witherell, Speaking Notes from the Press Seminar About the Environment and Labour in the Multilateral Agreement in Investment (Mar. 26, 1998). 
But, by that time, the NGO campaign had succeeded in raising public opposition to the MAI. Five prominent member states of the OECD had instituted some form of parliamentary review of the MAI. ${ }^{181}$ The review commissioned by the French government was highly critical of both the negotiation procedure and provisions of the MAI. 182 This report, coupled with a strong concern as to the treatment of cultural industries under the MAI, led to France's withdrawal from negotiations on October 14, 1998 (one week before the MAI negotiations were set to resume). The French withdrawal signaled the death-knell for the agreement. Less than two months later, the OECD announced that negotiations would cease, resulting in no final agreement. 183

\subsection{The MAI Provisions: Extending the NAFTA Chapter 11 Model}

Various draft texts of the MAI were produced between 1997 and 1998.184 This part of the analysis is based on the last version of the agreement, which was produced on April 24, 1998 and released by the OECD on the Internet. 185 The draft MAI contains twelve chapters and encompasses 145 pages. Despite its length, the majority of clauses in the draft text deal with recognized disciplines in investment liberalization, investment protection, and dispute settlement. ${ }^{186}$ The MAI negotiators referred to these disciplines as the "three key areas of foreign direct investment rule-making." 187 This is not suprising given that the mandate of the MAI exercise was to deliver an agreement with "high standards" in those areas. The

151 These member states were Australia, Canada, France, Great Britain, and the United States.

182 See CATHERINE LALUMIÈRE \& JEAN-PIERRE LANDAU, RAPPORT SUR L'ACCORD MuLTILATÉRAL SUR L'INVESTISSEMENT (1998).

183 Press Release, OECD, Informal Consultations on International Investment (Dec. 3, 1998).

184 For an overview of the negotiating process leading to the last version of the agreement, see Dymond, supra note 170, at 28-33.

185 MAI NEGOTIATING TEXT, supra note 170 . See also OECD, THE MuLTILATERAL AGREEMENT ON INVESTMENT: COMMENTARY TO THE CONSOLIDATED TEXT, Apr. 22, 1998, DAFFE/MAI(98)/8/REV1 [hereinafter MAI COMMENTARY] (noting general arguments behind and discussions relating to the drafting of the MAI).

186 MAI NEGOTIATING TEXT, supra note 170, at 13-56 (ch. III Treatment of Investors and Investments), 56-61 (ch. IV Investment Protection), \& 62-75 (ch. V Dispute Settlement).

187 William $\mathrm{H}$. Witherell, Opening Address, in OECD, MULTILATERAL AGREEMENT ON INVESTMENT: STATE OF PLAY IN APRI 1997, at 13 (OECD, Working Articles, Vol. V, No. 51, 1997). 
MAI negotiators did go beyond these core issues to consider disciplines in what they termed "new matters."188 However, these "new matters" were, at least initially, further disciplines of interest to foreign investors that also includes prohibitions or limits on performance requirements, 189 the ability to freely transfer both profit and capital out of the host state, ${ }^{190}$ and rights of access and residence for key foreign personnel.191

The next Section of the Article will consider the key components of the MAI on scope of application, investment liberalization, protection, and dispute settlement. Within these core disciplines, the MAI provisions represented almost a facsimile (albeit strengthened in some respects) of the NAFTA Chapter 11 model. In turn, the facsimile included many of the problems identified in Section 4 of this Article that are inherent in the NAFTA model.

\subsubsection{Scope of Application}

Like NAFTA, the MAI adopted an asset-based definition of "investment."192 However, the MAI went beyond the NAFTA ap-

188 William S. Dymond, State of Play of the MAI Negotiations, in OECD, Multilateral Agreement on INVESTMENT: State OF Play AS OF Feb. 1997, at 8 (OECD, Working Articles, Vol. V, No. 8, 1997).

189 MAI NeGOTIATING TEXT, supra note 170, at 18-26.

190 Id. at $59-60$.

191 Id. at 14-17.

192 Article 2 of Chapter II of the MAI defines "investment" as:

Every kind of asset owned or controlled, directly or indirectly, by an investor, including:

(i) an enterprise (being a legal person or any other entity constituted or organised under the applicable law of the Contracting Party, whether or not for profit, and whether private or government owned or controlled, and includes a corporation, trust, partnership, sole proprietorship, branch, joint venture, association or organisation);

(ii) shares, stocks or other forms of equity participation in an enterprise, and rights derived therefrom;

(iii) bonds, debentures, loans and other forms of debt, and rights derived therefrom;

(iv) rights under contracts, including turnkey, construction, management, production or revenue-sharing contracts;

(v) claims to money and claims to performance;

(vi) intellectual property rights;

(vii) rights conferred pursuant to law or contract such as conces- 
proach in several important respects. First, the MAI definition is an open definition; it lists items that are included and implies that non-listed items are also covered. In contrast, Article 1101 of NAFTA adopts a closed definition of investment, which states what is included in the definition and what is not. ${ }^{193}$ There is also a more subtle distinction between the two definitions. The NAFTA definitions require certain assets to have particular characteristics before they will be defined as an investment and enjoy the benefits of coverage under that treaty. Characteristics such as the commitment of capital and the assumption of risk delineate the coverage of investment under NAFTA. ${ }^{194}$ There is no consideration of these characteristics in the MAI definition. ${ }^{195}$ Again, this may have been due to the confidence of the negotiators at the commencement of MAI negotiations. In 1995, the global economy had been marked by a continuous growth in investment flows since the mid-1980s. This stability and the desire to draft a "high standards" agreement may have led MAI negotiators to try to cover as many forms of capital flow as possible.

This broad approach is unlikely to be acceptable to developing countries, which have traditionally insisted on the right to regulate forms of investment less permanent than FDI. Concern as to the rate of outflow of portfolio investment during the Asian financial crisis led Malaysia to introduce currency restrictions in September 1998.196 Further, the 1998 Framework Agreement on the ASEAN Investment Area explicitly excludes portfolio investment from the coverage of that agreement. 197 Even within the supposedly like-

sions, licenses, authorisations, and permits;

(viii) any other tangible and intangible, movable and immovable property, and any related property rights, such as leases, mortgages, liens and pledges.

Id. at 11 .

193 See infra Section 4.1.1. (discussing the scope of Article 1101).

194 Id.

195 There is, however, a footnote to the draft Article 2 of Chapter II (which defines "investment" in the MAI) suggesting that an interpretative note will be required to set out these characteristics. MAI NEGOTIATING TEXT, supra note 170, at 11 n.2.

196 See supra notes 169-74 and accompanying text (citing sources discussing the Asian Financial Crisis).

197 Article 2 of the Framework Agreement on the ASEAN Investment Area delineates the coverage of the agreement along the following lines: "This Agree- 
minded OECD states, certain delegations argued for the exclusion of portfolio investment from the MAI definition and others found it difficult to accept an open definition. ${ }^{198}$

\subsubsection{Investment Liberalization}

Like NAFTA, the MAI aimed to liberalize restrictions imposed on investors by preventing member states from discriminating between foreign and domestic investors. Again, like NAFTA, the MAI applied the non-discriminatory standards of national treatment and most-favored-nation treatment to both the pre- and postadmission phase of the investment process. ${ }^{199}$

The inclusion of the MAI model into these sovereignty-based grounds for excluding entry of foreign investors was also magnified by the way in which the agreement effected liberalization commitments. Like NAFTA, the MAI adopted a top-down model of liberalization, the starting point being the rights set out in the agreement, which ostensibly applied to all economic sectors in the host state unless exempted in the agreement by the contracting party. Aside from general exceptions, which applied to all or most of the MAI, ${ }^{200}$ member states could also lodge country-specific exceptions to carve out particular discriminatory legislation from the operation of the MAI.201

The top-down structure of the MAI was particularly problematic with regards to the rights of entry provided under the agreement. Given the often sensitive political grounds for restricting entry, the top-down approach forces contracting parties to be overly cautious and lodge extensive exceptions to liberalization commitments. Indeed, in early 1997, the Chairperson of the MAI Negotiat-

ment shall cover all direct investments other than portfolio investments; and matters relating to investment covered by other ASEAN Agreements, such as the ASEAN Framework Agreement on Services." Framework Agreement on the ASEAN Investment Area, available at http://www.vietnamese-law-consultancy .com/intergration/asean_main.htm (last visited Oct. 16, 2002).

198 LESSONS FROM THE MAI, supra note 171, at 11.

199 MAI NEGOTIATING TEXT, supra note 170, at 13 . The reference to "establishment" and "acquisition" in the national treatment and most-favored-nation treatment clauses indicate that these provisions were intended to extend to both pre and post-admission of foreign investment. Id.

200 These general exceptions enabled member states to impose restrictions on foreign investment on national security, public order, balance of payment, and prudential and taxation grounds. Id. at 76-88.

201 Id. at 89-94. 
ing Group proposed that member states table their proposed exceptions prior to completion of the Agreement. The purpose of this was to reach the highest level of liberalization at the outset by negotiating away proposed country specific exceptions. The negotiators took the view that "[t]hese [country specific] reservations will be the essential measuring rod against which can be judged the value of the rights and obligations of the MAI and, in large measure, determine the readiness of countries to adhere to the MAI."202

But the Chairperson's proposal led to a surprisingly high number of exceptions amongst supposedly liberal, like-minded states. ${ }^{203}$ The potentially unwieldy outcome of this approach was also exacerbated by the fact that negotiators had not reached a final agreement on how the MAI would progressively liberalize (or "rollback") non-conforming country-specific measures. ${ }^{204}$

This point reinforces a fundamental difference between applying non-discriminatory standards in the trade rather than investment field. A commitment to reduce tariffs on entry of goods will never involve the political sensitivity of agreeing to the entry of a foreign investor to the host state. This makes it inherently more difficult to engender public and political support for a top-down rather than GATS-like bottom-up approach to investment liberalization. Indeed, the MAI experience has shown that contracting parties are likely to act cautiously in this respect and submit a veritable telephone book of non-conforming measures.

Aside from the non-discriminatory standards of treatment, the MAI also replicated NAFTA in terms of an absolute prohibition on the use of a number of performance requirements. ${ }^{205}$ But the MAI prohibition encompasses an even larger number of performance requirements than NAFTA. 206 These requirements go substantially

202 William A. Dymond, The Main Substantive Provisions of the MAI, in OECD, PROCEedings of THE SPECIAL Session of THE MUltilateral AGREEMENT ON INVESTMENT HELD IN PARIS ON 17 SEPT. 1997, at 16 (OECD, Working Articles, Vol. V, No. 96, 1997) (emphasis added).

203 LESSONS FROM THE MAI, supra note 171, at 12; Commonwealth of Australia (Department of Treasury), Australia: Revised Schedule of Preliminary Reservations (Oct. 1997). Australia's reservations to the MAI essentially preserved most of its current system of regulating and screening the entry of foreign investors under its Foreign Acquisitions and Takeovers Act, 1975 (Austl.) and accompanying Ministerial statements.

204 MAI COMMENTARY, supra note 185 , at 60.

205 MAI NEGotiating TEXT, supra note 170, at 18-26.

206 For example, the MAI goes beyond the NAFTA approach in prohibiting a member host state from imposing performance requirements such as location of 
beyond the illustrative list in the TRIMS Agreement and include common mechanisms such as technology transfer requirements used by developing countries in their economic planning processes.

\subsubsection{Investment Protection}

Chapter IV of the MAI sets out the investment protection provisions of the draft MAI. Like NAFTA, the MAI contains strong provisions requiring host states to compensate investors in the event of expropriation of their investment. ${ }^{207}$ These provisions cover direct as well as indirect expropriations, with the latter covering governmental measures "having an equivalent effect" to a direct expropriation. ${ }^{208}$ The MAI provisions also replicate the drafting flaw in Article 1110 of NAFTA. There is no guidance within the MAI provisions as to whether normal regulatory changes that negatively affect the value of an investment would be covered within the concept of an indirect expropriation. Instead, the MAI negotiators simply assumed that this broad formulation would be accepted as:

[t]he draft [expropriation provision] has many similarities with well-known investment protection provisions found in hundreds of bilateral investment protection agreements. This is no surprise because it was never the intention of the negotiating partners to "re-invent the wheel," but rather to add some more spokes in order to strengthen the whole vehicle. ${ }^{209}$

The investment protection provisions also duplicate NAFTA Article 1105 by requiring member states to provide "fair and equitable treatment and full and constant protection and security" while ensuring a minimum standard of treatment of "that required by international law." 210

headquarters, research and development, employment of nationals, domestic joint venture participation, and minimum and maximum level of equity participation. See id. at 20-21 (referring to sections $1(\mathrm{~g}),(\mathrm{i}),(\mathrm{j}),(\mathrm{k})$, and (l), respectively).

207 Id. at 56-57.

208 Id. at 56.

209 Joachim Karl, Investment Protection, in OECD, supra note 178, at 14.

210 MAINEGOTIATING TEXT, supra note 170 , at 56. 
This unwillingness to critically assess the broad NAFTA approach to investment protection is symptomatic of the approach of the negotiators to the MAI exercise generally. It was only in 1998 that the MAI negotiators made a belated attempt to address some of the public concerns (engendered largely by the NGO campaign) about the broad operation of the NAFTA-inspired investment protection provisions.

\subsubsection{Dispute Settlement}

Like NAFTA, the MAI contains both state-to-state and investorto-state dispute settlement procedures. ${ }^{211}$ It is notable that some countries objected to the extension of the investor-state dispute resolution procedure to the pre-establishment phase of the investment process. There was some concern about giving potential investors the standing to file a claim against a host state in which they were planning to invest. ${ }^{212}$

\subsubsection{Absences}

Like NAFTA, the MAI largely ignored the question of investment incentives. The provisions on performance requirements explicitly condone the use of incentives if linked to certain performance requirements. ${ }^{213}$ For incentives not linked to performance requirements, there are a variety of bracketed texts within the MAI. These range from texts which state that several delegations believe that no provisions are necessary, ${ }^{214}$ a proposal for considering the disciplines on incentives as part of the MAI built-in agenda for future work, 215 to a variety of articles that try to restrict the use of incentives from applying non-discriminatory standards of treatment to notification requirements under the MAI. ${ }^{216}$

The MAI also did not initially include a broad GATT Article $X X$-type exception. Instead, the MAI approach reflected the NAFTA model of strong liberalization and protection provisions with the ability of host states to exempt particular national measures as country-specific exceptions. But this limited approach

211 Id. at 62-76.

212 See LESSONS FROM THE MAI, supra note 171, at 19.

213 MAI NEGOTIATING TEXT, supra note 170, at 22.

214 Id. at 45 .

215 Id. at 46.

216 Id. at $46-47$. 
changed dramatically late in the negotiations in March of 1998. In the face of growing NGO and public opposition, the Chairperson of the MAI Negotiating Group released a package of changes to the text in an attempt to address the impact of the strong MAI provisions on core aspects of regulatory competency. ${ }^{217}$ The Chairperson's package is notable as the MAI is arguably the first ever multilateral commercial agreement to directly amend its provisions to take into account NGO concerns. It is considered next.

\subsection{Another Retreat: The Chairperson's Package Proposing Changes to the MAI}

A draft of the MAI was leaked to Public Citizen, a U.S. consumer NGO, in February 1997.218 Up until that date, the MAI had been a confidential working document. Public Citizen immediately published the draft negotiating text on the Internet, where it became "available to anyone with a computer and a modem." 219 The release of the negotiating text on the Internet led to an explosion of concern about the MAI amongst a bewildering range of NGOs. Environmental groups joined with domestic trade unions, international human rights groups, developmental bodies, religious organizations, and churches in opposing the MAI.220

Much of the NGO opposition to the MAI was based on a general anxiety about the process of economic globalization and focused on issues such as the increasing economic power of transnational corporations ${ }^{221}$ and the impact of the MAI on the sovereignty

217 OECD, Chairman's NOTE ON ENVIRONMENT AND RELATED MatTERS ON LABOUR, DAFFE/MAI(98)10 (Mar. 9, 1998) [hereinafter CHAIRMAN's NOTE].

218 Kobrin, supra note 172, at 98.

219 Id.

220 For an indication of the types of NGOs that opposed the MAI, see generally Kobrin, supra note 172 (discussing the NGO ambush of the MAI); MAUDE BARLOW \& TONY CLARKE, MAI: THE MULTILATERAL AGREEMENT ON INVESTMENT AND THE THREAT TO AMERICAN FREEDOM (1998) (examining the North American NGO campaign against the MAI); STOPPING THE JUGGERNAUT: PUBLIC INTEREST VERSUS THE MULTILATERAL AGREEMENT ON INVESTMENT (James Goodman \& Patricia Ranald eds., 2000) (examining the different NGOs opposed to the MAI in Australia and their interaction with groups in other countries).

221 For example, a prominent Canadian NGO characterized the MAI as "a power grab for transnational corporations that would end up hijacking the fundamental democratic rights and freedoms of peoples all over the world." POLARIS INSTITUTE, TOWARDS A CITIZENS' MAI: AN ALTERNATIVE APPROACH TO DEVELOPING A GLOBAL INVESTMENT TREATY BASED ON CITIZENS' RIGHTS AND DEMOCRATIC CONTROL, available at http://www.germanwatch.org/tw/citizmai.htm (last visited Oct. 13, 2002). 
of host states.222 Aside from their broad concerns with economic globalization, NGOs also used a more specific argument against the MAI; its facsimile of the NAFTA model and likely impact on the regulatory autonomy of host states. NGOs particularly focused on the close similarity between the investment protection provisions between NAFTA and the MAI. The settlement of the arbitral dispute brought by Ethyl Corporation against Canada under NAFTA Chapter 11 towards the end of the MAI negotiations also brought impetus to these claims. ${ }^{223}$ The concern that the MAI (by replicating NAFTA Article 1110-type protection against indirect expropriation) would inhibit normal regulatory measures underlined much of specific NGO opposition to the MAI:

222 For example, the Western Governors' Association, an American advocacy NGO, prepared a report easily accessible on its Internet web-site that detailed state-by-state specific laws that might be threatened were the United States to sign the MAI. WESTERN GOVERNORS' ASSOCIATION, MULTILATERAL AGREEMENT ON INVESTMENT: POTENTIAL EFFECTS ON STATE \& LOCAL GOVERNMENT, available at http://www.westgov.org /wga/publicat/maiweb.htm (last visited Oct. 13, 2002). The same approach was taken by Friends of the Earth, an international environmental NGO, which cited a variety of pro-environmental laws, which it claimed would be contrary to the MAI. FRIENDS OF THE EARTH, EXAMPLES OF LAWS THAT WOULD CONFLICT WTTH THE MAI, available at http://www.foe.org/international /trade/mai/shortlaws.html (last visited Jun. 8, 1999). In contrast, the text of the MAI, which was released by the OECD on the Internet, did not include the country-specific exceptions lodged by member states to the MAI. MAI NEGOTIATING TEXT, supra note 170 . This led to the mistaken perception that all laws that discriminated against foreign investors (even in sensitive policy areas) would be liberalized.

223 In 1997, the Canadian government banned the import and inter-provincial transport of a fuel additive known as MMT. The purpose of the ban was ostensibly environmental; the Canadian government took the view that MMT was a direct source of harmful air pollutants and also caused more sophisticated automotive pollution control devices to malfunction. However, the ban did not prohibit the production and sale of MMT in Canada. As such, this legislative approach effectively prevented the sale of foreign-made MMT but not domestically-made MMT in Canada. Ethyl Corporation, a U.S. company, was an importer and distributor of MMT in Canada. Ethyl challenged the ban under Chapter 11 of NAFTA, arguing that the ban breached Articles 1102 (National Treatment), 1106 (Performance Requirements), and 1110 (Expropriation), and claimed damages of U.S. $\$ 251$ million. Canada responded to Ethyl Corporation's claims by challenging the jurisdiction of the arbitral tribunal. In June 1998, the arbitrators rejected most of Canada's challenge and postponed the rest to a consideration with the merits of the case. But the tribunal never reached a decision on the merits. In July 1998, presumably in response to the adverse decision on jurisdiction, Canada agreed to settle the dispute, lift its ban on MMT, and pay Ethyl Corporation U.S. $\$ 13$ million in compensation. The settlement occurred at the height of the NGO campaign against the MAI. For a summary description of the facts in the dispute, see NAFTA Chapter 11 Arbitral Tribunal: Ethyl Corporation v. The Government of Canada (Award on Jurisdiction) vol. 38, 38 I.L.M. 708, 710-17 (June 24, 1998). 
Perhaps the greatest environmental threat the MAI poses is that, under the investor-state dispute procedure, any new laws to protect the environment, wilderness, species or natural resource production could be considered a form of "expropriation" and foreign investors would have the right to sue for compensation before an international tribunal made up of unelected trade bureaucrats. 224

The NGO campaign reaped dividends on this point late in the negotiations. On March 9, 1998, the Chairperson of the MAI Negotiating Group released a package proposing changes to the draft MAI "to achieve balance between MAI disciplines and other important areas of public policy of concern to MAI Parties and to avoid unintended consequences on normal regulatory practices." 225

The package contains a variety of different initiatives varying in degrees of strength and specificity. At one end of the spectrum, it proposed the inclusion of preambular references to international declarations on the environment and labor. At the other end of the spectrum, there were more substantive attempts to address some of the problems of replicating the NAFTA Chapter 11 model. Within the liberalization commitments, the package proposed an interpretative note to the national treatment and most-favorednation treatment provisions regarding the impact of the phrase "in like circumstances." 226 The intent of this note was to deal with the difficult problem of determining when de facto discrimination will constitute a breach of the national treatment norm. The underlying aim of the interpretative note was to "preserve the necessary scope for non-discriminatory regulation." 227 Of itself, there is little sub-

224 BARLOW \& CLARKE, supra note 220, at 60 (emphasis added).

225 CHAIRMAN'S NOTE, supra note 217, at 2.

226 The relevant part of that interpretative note reads:

[G]overnments may have legitimate policy reasons to accord differential treatment to different types of investments.... The fact that a measure applied by a government has a different effect on an investment or investor of another Party would not in itself render the measure inconsistent with national treatment and most favoured nation treatment.... The objective of "in like circumstances" is to permit the consideration of all relevant circumstances, including those relating to a foreign investor and its investments, in deciding to which domestic or third country investors and investments they should appropriately be compared.

Id. at 5 .

227 Id. at 2. 
stantive guidance within the note. However, it may have provided an arbitral tribunal with a mandate to consider a broad range of circumstances (possibly including the policy objectives evident from the design and structure of a given regulatory measure) in its deliberative process. By comparison, NAFTA tribunals to date have largely taken a very restrictive view of similar wording in $\mathrm{Ar}-$ ticle 1102.228

The Chairperson's package also proposed an interpretative note to deal with the broad coverage of the MAI investment protection provisions. ${ }^{229}$ But this interpretative note attempts to remedy the broad scope of the MAI provisions with similarly broad interpretative language. This could conceivably lead to the kind of second-guessing of governmental intent in passing regulatory measures evident in the NAFTA Chapter 11 cases such as S.D. Myers. For example, an arbitral tribunal considering whether a given regulatory initiative is a "measure tantamount to expropriation" could then, under the interpretative note, try to discern whether it could be justified as being "in the public interest." It is difficult to see how an arbitral tribunal (summoned, in part, by the initiation of an action by a foreign investor) is qualified to make this kind of judgment. This highlights the problem of trying to tinker with the edges of a substantive provision that has its origins in another time and place. The strong guarantees of investment protection in both the MAI and NAFTA have their bases in similar BIT language de-

228 See supra note 129 and accompanying text on the analysis of "like circumstances" in the S.D. Myers case. See also In the Matter of an Arbitration Under Chapter Eleven of the North American Free Trade Agreement Between Pope \& Talbot, Inc. and the Government of Canada, Award on the Merits of Phase 2, paras. 73-104, (Apr. 10, 2001) (providing an example of NAFTA's interpretation of Article 1102), available at http://www.dfait-maeci.gc.ca/tna-nac/Award_Merits-e.pdf.

229 The interpretative note reads:

Interpretative Note: Articles-on General Treatment, and-on Expropriation and Compensation [sic], are intended to incorporate into the MAI existing international legal norms. The reference in Article IV.2.1 to expropriation or nationalisation and "measures tantamount to expropriation or nationalisation" reflects the fact that international law requires compensation for an expropriatory taking without regard to the label applied to it, even if title to the property is not taken. It does not establish a new requirement that Parties pay compensation for losses which an investor or investment may incur through regulation, revenue raising and other normal activity in the public interest undertaken by governments. Nor would such normal and non-discriminatory government activity contravene the standards in Article-.1 (General Treatment) (emphasis added).

CHAIRMAN'S NOTE, supra note 217 , at 6 . 
veloped in response to threats of expropriation in the 1950s and 1960s. Within the context of a proposed WTO investment agreement, WTO negotiators should consider carefully whether such broad language is warranted in a global economy marked by increasing competition to attract foreign investment.

The Chairperson's package extended beyond proposing interpretative notes to suggesting direct amendments to provisions in the MAI text. These included a NAFTA-inspired provision requiring member states not to lower domestic standards to attract investment ${ }^{230}$ and a proposal to annex the non-binding OECD Guidelines for Multinational Enterprises to the text of the MAI.231 Other amendments addressed existing provisions such as the proposal for a limited exception to the prohibition on performance requirements to allow certain requirements to be undertaken for environmental reasons. ${ }^{232}$ But these were not the only substantive changes. The package goes so far as to suggest a provision affirming the right of member states to pass domestic regulatory measures otherwise consistent with the MAI: "A Contracting Party may adopt, maintain or enforce any measure that it considers appropriate to ensure that investment activity is undertaken in a manner sensitive to health, safety or environmental concerns, provided such measures are consistent with this agreement." 233

This proposal is somewhat puzzling. It is largely meaningless, as it only applies to measures consistent with the MAI. If a regulatory measure complies with the non-discriminatory and other norms in the MAI, it will already be valid under the agreement. If the proposal's intention was to provide some form of exception for domestic regulatory measures, then the exception would logically have to apply to initiatives inconsistent with the MAI (which is the approach underlying GATT Article XX). The Chairperson's pack-

230 The provision states:

A Contracting Party shall not waive or otherwise derogate from, or offer to waive or otherwise derogate from, its domestic health, safety, environmental, or labour measures, as an encouragement to the establishment, acquisition, expansion, operation, management, maintenance, use, enjoyment and sale or other disposition of an investment of an investor.

Id. at 6.

231 Id. at 7. NAFTA.

${ }^{232}$ Id. at 6-7. This proposed change basically replicates Article 1106(6) of

233 Id. at 6 (emphasis added). 
age describes this proposal as a "targeted approach," but notes that "[a]nother approach would be a general exception inspired by GATT Article XX."234 Thus, in other words, the proposal is conceived as a form of exception that is mostly semantic.

The Chairperson's package encapsulates some of the problems in trying to deal with the impact of broad liberalization and protection provisions on regulatory autonomy through an exception-type amendment. In the context of a possible WTO investment agreement, the next Section of the Article will posit an alternative and, it is suggested, more stable response to this problem by suggesting a series of proposals to carefully delineate and define the operative provisions of such an agreement.

\section{THE WTO, FOREIGN INVESTMENT, AND THE DOHA AGENDA}

With the specter of the failed Seattle WTO Ministerial Conference in 1999 and on-going public demonstrations against economic globalization, WTO members were under great pressure to reach an agreement at the Doha Ministerial Conference in late 2001. In the lead-up to the Doha talks, a number of proposals were floated in order to breach expected opposition by developing countries to the inclusion of investment rules on the negotiating agenda. Most notably, the EU put forward a proposal for an essentially multilateral approach, enabling countries to opt out of final investment rules. ${ }^{235}$ Interestingly, at least in the initial stages of preparatory discussion before the Doha Ministerial Conference, the large caucus of developing countries under the "Group of 77" umbrella did not seem as implacably opposed to the inclusion of investment rules as expected.236 Yet, within this broad grouping, there was strong opposition by the so-called "Like Minded Group" of India, Malaysia and Pakistan, who resisted commencing negotiations on investment and merely sought further study on the possibility.237

234 Id. at 2.

235 See Neue WTO-Runde dank EU-Flexibiaet, NEUE ZÜERCHER ZEITUNG, Feb. 2425, 2001, at 10; Draft Declaration Presses for Decision on Investment, Competition, 1, 16-18 (39) INSIDE U.S. TRADE 17 (Sept. 28, 2001).

236 Group of 77 Pushes Concessions in Agriculture, Open to Investment Talks, 19 (43) INSIDE U.S. TRADE 17-18 (Oct. 26, 2001) [hereinafter Concessions in Agriculture].

237 Decision on Investment, Competition Talks Likely to Be Delayed, Special Report, INSIDE U.S. TRADE 3, 4 (Nov. 13, 2001) [hereinafter Decision on Investment]. In particular, India has long opposed the inclusion of investment on the negotiating agenda of the WTO. See generally Satya P. Das, An Indian Perspective on WTO Rules on Direct Foreign Investment, presented at the WTO South Asia Workshop 
But on the whole, developing countries were more concerned with matters such as the elimination of agricultural export subsidies, 238 reform of the use of anti-dumping and countervailing duty laws, 239 further talks on textiles 240 and the reform of the Agreement on Trade-Related Aspects of Intellectual Property Rights to enable governments to take necessary steps to protect public health.241 Not surprisingly, developing countries opposed the inclusion of environmental rules in the WTO, an area promoted strongly by the EU.242

In a break from the past, the United States was not as strong a demandeur for the commencement of investment negotiations in the Doha agenda. ${ }^{243}$ This may have been as a result of the failure of the primarily U.S.-backed MAI, the ongoing difficulties in the interpretation of Chapter 11 of NAFTA and the inter-agency disputes within the Bush administration on the extent to which language for future bilateral agreements with Singapore and Chile and even the regional FTAA should diverge from the NAFTA Chapter 11 model. ${ }^{244}$ Instead, the other members of the Triad (Japan and the EU) pushed forcefully for the commencement of negotiations on

in New Delhi (Dec. 1999) (offering a critique of the Indian negotiating position on the inclusion of investment on the negotiating agenda of the WTO).

238 Concessions in Agriculture, supra note 236.

239 The anti-dumping procedure under the Uruguay Round Antidumping Agreement (that can lead to the imposition of anti-dumping duties) tends to be typically initiated by developed states-particularly the United States, Australia, Canada and the EU-whilst developing countries are most often defendants rather than complainants. See generally WTO, ANNUAL REPORT 21 (2000) (reporting on various nations' stances on anti-dumping); TREBILCOCK \& HOWSE, supra note 46, at 166-71 (detailing further information on the initiation of anti-dumption actions). The desire of developing countries to commence negotiations for reform of the anti-dumping rules to prevent disproportionate use of anti-dumping measures is detailed in Concessions in Agriculture, supra note 236, at 17; WTO Draft Declaration Proposes AD Negotiations, Delays Environment, Special Report, INSIDE U.S. TRADE 1-2 (Oct. 30, 2001).

240 Concessions in Agriculture, supra note 236, at 17-18.

241 TRIPS-Public Health Declaration Splits Developing, Developed Nations, 19 (39) INSIDE U.S. TRADE 11, 12 (Sep. 28, 2001).

242 Lamy Says EU Must Have Ability to Negotiate Environment in WTO, 19 (45) INSIDE U.S. TRADE 11-12 (Nov. 9, 2001).

243 At Doha, U.S. Aims to Postpone Decision on Dumping, Weighs EU Plan, 19 (45) INSIDE U.S. TRADE 1-2 (Nov. 9, 2001).

244 See supra Section 4.3 (detailing the inter-agency deadlock and uncertainty in future trade and investment initiatives involving the United States). 
investment. 245 The strategic interests of the United States appear to have been to resist the push for negotiations to reform the use of anti-dumping and countervailing duty measures while advocating reform of agricultural rules to assist U.S. producers. ${ }^{246}$

\subsection{The Doha Ministerial Declaration}

The broad divergences between WTO member states in the lead up to the Doha Ministerial Conference set the scene for trading compensatory bargains across separate issues to achieve consensus for the start of negotiations. Unlike the failed Seattle Ministerial Conference in 1999, WTO Ministers succeeded in agreeing to an agenda to commence negotiations. The overall outcome of the Doha Ministerial Conference was to launch immediate negotiations on nine different topics, ${ }^{247}$ eight of which are to be concluded as a single undertaking 248 by January 1,2005 . The eight are implementation, agriculture, services, industrial tariffs, subsidies, antidumping, regional trade agreements and the environment. Negotiations on reform of the dispute settlement rules are to be concluded by May 2003.

From the perspective of developing countries, it might be slightly ambitious to describe the Doha agenda as a development round of negotiations. However, there were three primary areas of interest for developing countries included in the single undertaking negotiations. First, implementation of existing commitments is an issue for negotiations in its own right, together with a separate Decision on Implementation-Related Issues and Concerns. ${ }^{249}$ De-

245 See supra note 237 , at 4 (detailing last-minute efforts by the EU and Japan to secure support from developing countries for the inclusion of investment in the Doha agenda).

246 Zoellick Raises Two Objections to WTO Draft Declaration, 19 (44) INSIDE U.S. TRADE 21-22 (Nov. 2, 2001).

247 These are Implementation ( 12 ), Agriculture ( 13 ), Services ( 15 ), Industrial tariffs (\$ 16), Subsidies (ף 28), Anti-dumping (ף 28), Regional Trade agreements ( $(29)$, Environment ( $($ 31), and on a separate track, the Dispute Settlement Understanding (\$30). See Doha Ministerial Declaration, supra note 5. For an analysis of these topics as well as the Doha Declaration, see generally International Centre for Trade and Sustainable Development, The Doha Declaration's Meaning Depends on the Reader, 5 (9) BRIDGES (Nov./Dec. 2001).

248 The concept of a single undertaking means that nothing is finalized until negotiations are concluded in all areas. For an illustration of this point, see Doha Ministerial Declaration, supra note 5, I 47.

249 Doha Ministerial Declaration, supra note 5, ๆ 12 (separating issues of implementation and concerns); WTO, Implementation-Related Issues and Concerns, WT/MIN(01)/17 20 (Nov. 14, 2001). 
veloping countries have expressed concern with the lack of implementation of existing commitments virtually since the coming into force of the Uruguay Round set of agreements. Further, developing countries have succeeded in including anti-dumping and subsidy reform amongst the topics for immediate negotiation. The Doha declaration also contains long, substantial sections on topics such as technical assistance, capacity building, and leastdeveloped-countries. ${ }^{250}$ Aside from the negotiating program, a general work program was also launched on priority issues for developing countries such as trade and debt, 251 finance and technology transfer, ${ }^{252}$ as well as special and differential treatment. ${ }^{253}$

On the opposite side of the ledger, developing countries failed to include legally-binding language in the TRIPS Agreement to enable them to address public health emergencies. This was strongly resisted by the pharmaceutical industry on the basis that it would act as a giant carve-out for the TRIPS Agreement.254 Instead, a separate Declaration on the TRIPS Agreement and Public Health contains a political statement supportive of public health.255 Outside of the context of implementation issues, no substantial progress was made on further market access for textile products, a long-standing issue of interest for developing countries. This remains an inherently sensitive topic in many developed states, particularly the United States. Similarly, the issue of movement of people (rather than movement of goods or capital) was not addressed in the Doha agenda. While this is not suprising (given the even more politically sensitive aspects of this topic since the terror-

250 Doha Ministerial Declaration, supra note 5, ๆा 38-43.

251 Id. \$ 36.

252 Id. If 37.

253 Id. If 44.

254 See Fight over TRIPS Narrowed to Whether Declaration Would Be Binding, Special Report, INSIDE U.S. TRADE 3 (Nov. 13, 2001); WTO Countries in Deadlock on TRIPS, 1 (43) INSIDE U.S. TRADE 1, 22-23 (Oct. 26, 2001) (reporting on the pharmaceutical industry's objections to public health provisions).

255 See WTO, Declaration on the TRIPS Agreement and Public Health WT/MIN(01)/DEC/2 (Nov. 20, 2001), which reads as follows:

We agree that the TRIPS Agreement does not and should not prevent Members from taking measures to protect public health. Accordingly, while reiterating our commitment to the TRIPS Agreement, we affirm that the Agreement can and should be interpreted and implemented in a manner supportive of WTO Members' right to protect public health and, in particular, to promote access to medicines for all. 
ist attacks of September 11), this issue is of considerable interest to developing countries, given their comparative advantage in this area.256

Among the developed states, the EU scored a major victory with the immediate launch of negotiations on certain, albeit limited, environmental initiatives.257 As a trade-off, the EU agreed to relatively strong language in the agricultural mandate, particularly on reducing export subsidies.258 This is an area which pits the European Union against most of the WTO member states (and to a large degree, the United States). For the purposes of this Article, investment (pushed largely by the EU) was not included in the set of topics for immediate negotiations. There is, however, reference to the start of negotiations on investment rules in the future. Unexpectedly, ambiguity surrounds the exact parameters of this part of the Doha agenda.

\subsection{Is There Really an Agreement to Commence Negotiations on Investment?}

The most confusing aspect of the Doha Ministerial Conference revolves around the so-called Singapore issues of investment, competition policy, government procurement, and trade facilitation.259 On each of these issues, the Doha declaration provides that

256 See generally TREBILCOCK \& HOWSE, supra note 46, at 484-99 (analyzing the welfare implications of greater immigration flows and the absence of international rules on this issue). The on-going negotiations between the United States and Chile on a proposed FTA highlight the tensions involved in this area. Chile (with the support of the U.S. service industry) has consistently pushed for the inclusion of rights providing temporary entry for services personnel. This has been stringently opposed by the United States out of concern over their impact on immigration. U.S. Resists Chile Services Visa Push, but Looks for Model Accord, 20 (2) INSIDE U.S. TRADE, Jan. 11, 2002, at 1, 20-21.

257 The agreement to commence negotiations on the environment are limited to three approved areas: (i) the relationship between existing WTO rules and to the trade obligations in multilateral environmental agreements; (ii) the reduction of trade barriers to the sale of environmental goods and services; (iii) to clarify and improve WTO disciplines on fisheries subsidies. Doha Ministerial Declaration, supra note 5, \ा 31 .

258 The relevant part of the negotiating agenda reads, "Building on the work carried out to date and without prejudging the outcome of the negotiations we commit ourselves to comprehensive negotiations aimed at: substantial improvements in market access; reductions of, with a view to phasing out, all forms of export subsidies; and substantial reductions in trade-distorting domestic support." Doha Ministerial Declaration, supra note 5, ๆ 13.

259 In the lead-up to the WTO Ministerial Meeting in Singapore in 1996, developed countries pushed for the commencement of negotiations on each of these 
members, "agree that negotiations will take place after the Fifth Session of the Ministerial Conference on the basis of a decision to be taken, by explicit consensus, at that Session on modalities of negotiations." 260

Developed members of the WTO, such as the United States, viewed this language as a mandate to launch negotiations at the fifth Ministerial Conference in Mexico in 2003, but some developing countries have opposed this interpretation. In the last hours of the Doha conference, India extracted a statement from the Qatari Trade Minister Youssef Kamal in his role as the Chair of the Ministerial Conference, in which he stated that:

[M]y understanding is that at that [fifth Ministerial] ... decision would indeed need to be taken by explicit consensus before negotiations on [the Singapore issues] could proceed ... in my view, this would give each member the right to take positions on modalities that would prevent negotiations from proceeding after the Fifth Session of the Ministerial Conference until that Member is prepared to join an explicit consensus. ${ }^{261}$

The legal status of this statement is unclear. It is not attached to the official Ministerial Conference Declaration itself. Further, this interpretation seems at odds with the agreement in the Doha Declaration to treat " $[\mathrm{t}]$ he negotiations to be pursued under the terms of this Declaration" as "parts of a single undertaking." 262 This issue is also linked to the reciprocal balance of concessions

topics. The resistance of developing countries led to a compromise whereby Ministers only agreed to establish working groups to study the issues surrounding these topics. WTO, World Trade Organization: Singapore Ministerial Declaration WT/MIN(96)/DEC (Dec. 13, 1996) vol. 36, 36 I.L.M. 218 (1997), II 20-23. For an overview of negotiations between developed and developing countries on investment in the lead up to the Singapore Ministerial Conference, see also ZDENEK DRABEK, A MULTILATERAL AGREEMENT ON INVESTMENT: CONVINCING THE SCEPTICS 9 (WTO, Staff Working Article ERAD 98 05, 1998) (providing background information on the negotiations); Smythe, supra note 163, at 108-12.

260 Doha Ministerial Declaration, supra note 5, If 20 (Investment), If 23 (Competition Policy), If 26 (Government Procurement), \& If 27 (Trade Facilitation) (emphasis added).

261 For a description of the Indian position as well as an excerpt of the Chairman's statement, see Note from Qatar Chairman Yields Uncertainty on New WTO Issues, 19 (47) INSIDE U.S. TRADE 15, 16 (Nov. 23, 2001).

262 See Doha Ministerial Declaration, supra note 5, ๆा 45, 47. 
within the overall Doha agenda. If the commencement of negotiations (rather than the modalities on which they proceed) on these issues were blocked, then demandeur entities, like the EU and Japan, could justifiably see the negotiating package as unbalanced and resist negotiations in other areas.

Given the historical resistance of some developing countries to the issue of multilateral investment rules, it would seem that the demandeur countries will need to do two things to ensure negotiations start on investment in Mexico in 2003. First, careful consideration to developing countries' interests on issues other than investment within the agreed negotiating agenda (such as longstanding concerns on implementation of existing commitments) will go a long way to building consensus for the start of investment negotiations. Second, in the lead-up to the 2003 WTO Ministerial Conference, the work undertaken by the WTO Working Group on the Relationship between Trade and Investment in developing a framework for a proposed WTO investment agreement could also play a significant role in ensuring the start of negotiations in 2003.263 This will depend upon the extent to which the proposed framework for a WTO investment agreement balances both the interests of developed and developing countries. The next Section of the Article will put forward a series of suggestions for a WTO investment agreement, which attempt to achieve this aim. In doing so, the proposals tie together the lines of inquiry and lessons discerned from the analyses of NAFTA Chapter 11 and the MAI in the earlier Sections of this Article.

\subsection{Suggestions for a WTO Investment Agreement}

There are four principles that should shape any effort in structuring a framework for a WTO investment agreement. First, developing countries are unlikely to accept a "high standards" NAFTA or MAI-like model on investment liberalization and protection. Indeed, there is a need to shift away from the perception that negotiation of investment rules is a zero-sum game with the only outcome being either full liberalization or full protectionism. ${ }^{264}$ Liberalization of investment restrictions (especially on the

263 The Doha Declaration explicitly envisages that the Working Group on the Relationship Between Trade and Investment undertake this type of work in the period leading up to the Fifth Ministerial Conference in 2003. Id.

264 This valuable point on the way past investment negotiations have been perceived is set out in Muchlinski, supra note 168, at 133. 
question of admission of foreign investment) is an inherently politically sensitive process. Further, unlike tariff negotiations, these restrictions cannot be negotiated incrementally and there is uncertainty as to the quantification of the benefits in removing some restrictions, such as certain performance requirements. A WTO investment agreement will need to balance the clear benefits that can result from increased liberalization (and investment flows) with the reality that some countries will continue to take restrictive measures whether for political or developmental purposes. ${ }^{265}$

Second, the foregoing analysis has revealed a number of ongoing difficulties with the NAFTA Chapter 11 model, particularly in regard to the issue of regulatory autonomy. The WTO negotiators should not simply look to the NAFTA precedent as the only model available. The MAI negotiators unsuccessfully looked to the NAFTA Chapter 11 model and the inconclusive result raises a fundamental issue. Parts of the extremely strong provisions on liberalization, protection, and dispute settlement in the NAFTA Chapter 11 model are rooted in another time and place. In particular, the broad wording of the investment protection provisions (largely borrowed from similar U.S. BITs) was designed to deliver stability in the face of hostile expropriatory behavior by newly independent states in the Cold War era. In the last few decades, most developing countries have moved away from this type of behavior and have unilaterally begun to liberalize their national investment policies within developmental parameters, such as the use of performance requirements. Hence, broad and often undefined provisions in NAFTA, such as Articles 1105 (Minimum Standard of Treatment) and 1110 (Expropriation) seem somewhat anachronous in the current international environment. Foreign investors are now more interested in gaining entry and freedom to operate in a host state. Thus, the strategic focus of a WTO framework on investment should be more towards implementing liberalization commitments rather than guarantees of strict investment protection.

Third, WTO negotiators should be concerned with the likely prospect of NGO oversight. The perceived success of the NGO

265 This point is also replicated in the Doha agenda itself. The proposed work to be undertaken in the WTO Working Group on the Relationship Between Trade and Investment in advance of the Mexico Ministerial Conference in developing a framework "should reflect in a balanced manner the interests of home and host countries, and take due account of the development policies and objectives of host governments as well as their right to regulate in the public interest." Doha Ministerial Declaration, supra note 5, II 22. 
campaign against the MAI episode (as well as on-going concern from many NGOs with NAFTA Chapter 11) will spark similar opposition by these groups in future investment initiatives. At a minimum, WTO negotiators should strive for a greater degree of transparency in the negotiating process than that shown in the MAI episode. A clear explanation of the objectives and components of a WTO investment agreement may in fact pre-empt some NGO concerns.

Fourth, NGO oversight is in many ways linked to the greater emphasis in developed states (particularly the EU) on the so-called linkages between international economic initiatives and matters such as the environment and labor. These issues should not be simply dismissed as protectionist tendencies driven by interest groups in developed states. Instead, WTO negotiators should aim to recapture some of the broadness of vision encapsulated within the Havana Charter that set down a mix of liberal and regulatory initiatives. This may, to some degree, conflict with the interests of developing countries who have historically resisted initiatives in this area. But increasingly, matters such as the relationship between investment flows and domestic environmental and labor standards cannot be artificially separated. The key to resolving this tension will be to devise reasonable proposals that balance divergent interests in this area.

Incorporating these four underlying themes, the following are modest but realistic suggestions for the drafting of a WTO investment agreement:

\subsubsection{Scope: A Narrower Definition of "Investment"}

The way in which "investment" is defined will be crucial in delineating the scope of operation of a WTO investment agreement. Developing countries are unlikely to accept coverage of short-term and often speculative capital flows, such as portfolio investment. Hence, WTO negotiators should aim to develop a narrower, assetbased definition of "investment" than that set out in NAFTA and the MAI. At one end of the spectrum, negotiators could simply limit the coverage of the agreement to FDI. Alternatively, the definition of "investment" could go beyond FDI to encompass a closed list of assets that the negotiating group is able to reach consensus on. This list of assets could isolate the key characteristics of the types of capital flow of most benefit to developing states. For example, other assets that could conceivably fall within this category 
are intra-firm debt or even debt with a relatively long-term perspective. If developing states agreed to go beyond FDI to include other forms of capital, this could be used to garner further concessions from developed countries in areas of strategic interest such as disciplines on the use of investment incentives.

\subsubsection{Liberalization}

The non-discriminatory standards of national and mostfavored-nation treatment should remain as the cornerstone of a WTO investment agreement. However, the question remains as to what forms of national regulation these standards should apply. This difficult question breaks down into two sub-questions. First, to which of the de jure discriminatory measures (as described in Section 3) should the liberalization provisions apply? For example, should a WTO agreement extend to pre-admission restrictions? Further, should there be some limitation on the use of investment incentives? How should a WTO investment agreement deal with the problem of de facto discriminatory measures? That is, how should the investment agreements deal with those regulatory measures which do not on their face discriminate against foreign investors but have some incidental, adverse impact? The following are possible solutions to these questions.

\subsubsection{Pre-Admission Restrictions: A GATS Bottom-Up Structure}

Entry by foreign investors into a host state is an inherently politically sensitive question. As such, a WTO agreement could simply exclude the coverage of national and most-favored-nation treatment from the pre-admission phase of the investment process. This would allow host states to freely regulate the question of entry by investors. But, as an alternative option (considering the likelihood of the demandeurs pushing forcefully for some kind of treatment of pre-establishment restrictions), the WTO negotiators could consider a GATS-like, bottom-up approach to scheduling commitments on pre-establishment matters. ${ }^{266}$ This would then give host

266 Indeed, this is envisaged in the set of issues to be addressed by the WTO Working Group on Trade and Investment in the lead-up to the Mexico Ministerial Conference. See Doha Ministerial Declaration, supra note 5, II 22 (listing areas that the Working Group on the Relationship Between Trade and Investment will focus on for clarification ). 
states significant discretion to specify which economic sectors of the national economy would be open to entry by foreign investors.

\subsubsection{Post-Admission Restrictions: A Top-Down Structure}

Once an investor enters into a host state, most restrictions imposed on it are motivated by the desire to fully capture the economic benefits of the foreign investment. For these restrictions, a WTO agreement should follow the stricter NAFTA and MAI approach of applying liberalization conditions on a top-down basis. Under this approach, the liberalization conditions would apply across all economic sectors and national laws of a WTO member unless specifically exempted by the submission of a negative-list of such measures. Careful consideration will need to be given as to the techniques in which to affect a system of progressive liberalization of these non-conforming measures. The guiding principle should be one of caution by specifying realistic time periods in which to initiate such procedures.

\subsubsection{The Grand Bargain: Investment Incentives/Performance Requirements}

A WTO investment agreement should discipline the use of investment incentives. This is an area in which developing countries can potentially gain the most from an investment agreement. Incentives are arguably as economically distortive as negative restrictions on foreign investors, such as performance requirements. Further, developing states are at a comparative disadvantage to developed states in their use of incentives. However, the absence of such disciplines in both the MAI and NAFTA evidences the historical resistance in the OECD states to disciplining these forms of positive discrimination in favor of foreign investors.

On the other side of the ledger, it would not be unexpected for developed states to seek to expand the list of performance requirements subject to the TRIMS Agreement in a WTO investment agreement. ${ }^{267}$ This scenario would provide WTO negotiators with the type of intra-issue linkage to meet the strategic interests of both

267 For example, the United States has long opposed the use of technology transfer requirements, which are not explicitly covered by the TRIMS Agreement. See Building American Prosperity, supra note 54, at xii ("Recommendation 6: Foreign Direct Investment Liberalization.... Forced technology transfer as a precondition for foreign direct investment should be actively opposed by the U.S. government."). 
sets of parties; they have a balancing interest in imposing moderate discipline on the use of investment incentives against further commitments to limit the use of performance requirements.

\subsubsection{National Treatment and the Difficult Question of De Facto Discrimination}

A national treatment obligation in a WTO investment agreement should clearly apply to regulatory measures that discriminate on their face against foreign investors. The more difficult task is figuring out how a national treatment norm in an investment agreement should deal with de facto discriminatory measures. To date, this issue has not received the attention it deserves in existing institutional fora. Within NAFTA case law, the implications of the operation of the national treatment norm have largely been overshadowed by analyses of the broad wording of the investment protection provisions in Articles 1105 (Minimum Standard) and 1110 (Expropriation). The primary focus of the interpretation issued by the NAFTA Free Trade Commission was to limit the operation of Article 1105. However, within the context of a proposed WTO investment agreement, it will be relatively easy to proscribe the operation of investment protection provisions by carefully defining their application. On a conceptual level, this is much more difficult to do with the application of the national treatment norm. Thus, this is where the WTO Working Group on Trade and Investment should focus its efforts in the lead-up to the Mexico Ministerial Conference.

While there is no ready and simple answer to this difficult issue, there are two fundamental points that should be considered in answering this question. First, protectionist intent (as discerned through statements made by regulators) should not be enough to constitute a finding of de facto discrimination. This was the path taken in S.D. Myers and, as has long been recognized in WTO jurisprudence, is a path beset by dangers, particularly from a legitimacy perspective. Thus, as a second principle, the focus should be on the discriminatory impact of the particular measure. In turn, should it be enough to simply identify (rather than quantify) an adverse impact on a foreign investor to ground claims breach of the national treatment norm? This has long been the approach within the GATT/WTO in the oft-stated principle that the focus of GATT Article III on national treatment is to protect competitive 
opportunities and expectations. ${ }^{268}$ However, GATT Article III.4 is limited in its operation by the fact that national treatment is only applied to "like products." Thus, the overall scope of Article III.4 is restricted by an analysis of whether two products are sufficiently similar (whether in their physical characteristics or through other criteria such as tariff classifications) to justify the application of the national treatment norm. In contrast, the national treatment clause in NAFTA Chapter 11 uses the formulation "in like circumstances," which, to date, has not been used by arbitral panels as a means by which to draw some boundary around the operation of that clause. ${ }^{269}$ Consequently, it is conceptually difficult to see any real limit to the operation of a national treatment clause along the lines of NAFTA Article 1102. Thus, it is suggested that attention should be given in the WTO Working Group on the issue of quantifying what level of adverse impact on a foreign investor is sufficient to ground a claim of breach of national treatment. Again, there is no simple or ready answer to this difficult question. But to some degree, the answer may partly lie in providing guidance (possibly in the form of interpretative note and careful drafting of the "in like circumstances" qualification) to a panel considering the application of a national treatment provision in a WTO investment agreement. It is essential that a WTO panel considering the impact of a given regulatory measure not approach its task with an assumption of protectionism. This is a disturbing trend clearly evi-

263 See, e.g., Report of the WTO Appellate Body, Japan - Taxes on Alcoholic Beverages, WT/DS8/AB/R; WT/DS10/AB/R;WT/DS11/AB/R (Oct. 4, 1996), para. F

(The broad and fundamental purpose of Article $\mathrm{II}$ is to avoid protectionism in the application of internal tax and regulatory measures.... Toward this end, Article III obliges Members of the WTO to provide equality of competitive conditions for imported products in relation to domestic products... Moreover, it is irrelevant that the 'trade effects' of the tax differential between imported and domestic products, as reflected in the volume of imports, are insignificant or even non-existent; Article III protects expectations not of any particular trade volume but rather of the equal competitive relationship between imported and domestic products.) (emphasis added),

available at http://www.wto.org/english/tratop_e/dispu_e/distabase_e.htm

269 See North American Free Trade Agreement Arbitral Panel Established Pursuant to Chapter Twenty, In the Matter of Cross-Border Trucking Services, Secretariat File no. USA-MEX-98-2008-01, para. 7, Feb. 6, 2001 (adopting a narrow market access interpretation of the phrase "in like circumstances" in the context of national treatment for cross-border services under Article 1202 of NAFTA), available at http://www.sice.oas.org/DISPUTE/nafta/english/U98081ae.asp. 
dent in some of the NAFTA Chapter 11 cases.270 As previously pointed out elsewhere, regulation of risk is a norm in the modern regulatory state and not an inherently suspicious intervention in free markets. ${ }^{271}$

\subsubsection{Investment Protection: A Step Back}

In devising clauses dealing with investment protection, negotiators should bear in mind the contemporary environment surrounding foreign investors and host states, particularly developing states. Foreign investors are generally more interested in gaining entry and freedom of operation in a host state rather than in protecting existing investments in recently de-colonized host states. In other words, the emphasis in a WTO investment agreement should be on investment liberalization rather than protectionism. This interest has been bolstered by the problems that have arisen from the overly broad NAFTA Chapter 11 protection provisions of Articles 1105 (Minimum Standard of Treatment) and 1110 (Expropriation).

With this in mind, there are two proposals for the investment protection provisions of a WTO investment agreement. First, negotiators should give careful thought to simply not including a minimum standard of treatment clause along the lines of NAFTA Article 1105. If the demandeur countries are successful in insisting on including such a clause, then the negotiators should carefully define the exact parameters of its application such as, for example, guarantees of transparency and due process in domestic legal proceedings. In contrast, there is much greater justification in including a clause along the lines of NAFTA Article 1110 guaranteeing compensation in the event of expropriation. The scope of that protection, however, should be limited to direct expropriation. Negotiators should strongly resist extending this standard of protection to so-called creeping or indirect expropriation.

270 See In the Matter of an Arbitration Under Chapter Eleven of the North American Free Trade Agreement Between Pope \& Talbot, Inc. and the Government of Canada, Award on the Merits of Phase 2, para. 70, Apr. 10, 2001, available at http://www.dfait-maeci.gc.ca/tna-nac/Award_Merits-e.pdf.

We have already seen that it is not always clear whether a measure is a de jure or de facto case, but even if it were, Canada has presented no reasons to justify treating the two forms of disadvantage differently. Indeed, the recognition that national treatment can be denied through de facto measures has always been based on an unwillingness to allow circumvention of that right by skillful or evasive drafting.

271 Howse, supra note 98 , at 156. 


\subsubsection{Dispute Settlement}

It is unlikely that the WTO negotiators will develop investorstate dispute settlement procedures in a WTO agreement.272 Indeed, if dispute settlement is limited to WTO member states, this could possibly limit the potential for some of the NAFTA Chapter 11 difficulties as investors would not have a direct route in which to challenge regulatory measures. But, as examined earlier in the Article, there are strong normative justifications for the inclusion of investor-state dispute resolution procedures. If the WTO negotiators do decide to tackle this issue, the likelihood of recreating the problems that have arisen in NAFTA will be reduced if the substantive provisions of a WTO investment agreement are carefully delineated.

\subsubsection{Investor Responsibilities}

The theme of preferring the interests of foreign investors (rather than focusing on their responsibilities) underlined much of the NGO opposition to the MAI. This is a theme that should not be simply rejected out of hand by WTO negotiators. For example, consideration should be given to the approach taken late in the MAI of the annexation of the OECD Guidelines on Multinational Enterprises to a WTO investment agreement. ${ }^{273}$ It is also clear that NGO groups will once again push strongly for wording on the impact of foreign investment on domestic environmental and labor standards. On these issues, a degree of caution is warranted. Clearly, developing states will most likely resist imposition in this area as an unjustified attack on areas of legitimate comparative advantage. If the WTO negotiators decide to tackle these areas of linkage, they would best be served by working within the traditional GATT/WTO formulation of negative integration (devising disciplines on what member states should not do) rather than moving towards any suggestion of positive harmonization (imposing

272 In the lead-up to the Mexico Ministerial Conference, the Doha agenda only countenances further work on the clarification of "consultation and the settlement of disputes between Members." Doha Ministerial Declaration, supra note 5, at 22.

273 For a creative suggestion to counter the perception of bias in favor of investor rights, see TREBILOCK \& HowSE, supra note 46 , at 366 . The authors suggest that, in a future investment agreement, the right to investor-state dispute settlement could be conditioned on agreement by investors to abide by the OECD Guidelines. 
positive obligations). In this vein, one possible approach is to include a provision requiring WTO members not to lower their labor or environmental standards in order to attract investment. The advantage of this approach is that it does not force WTO members to adopt a particular standard of environmental or labor protection but to simply not lower their chosen standards to attract foreign investors. There is a similar provision in NAFTA. On a slightly more ambitious note, such a commitment could even be framed to build in some role for NGO oversight (just as in NAFTA sideagreements on labor and environment) by creating a mechanism that identifies countries that have dropped their domestic standards to attract foreign investors. Whilst this type of proposal will no doubt provoke opposition amongst some WTO member states, it would be an ideal opportunity in which to constructively harness NGO expertise as well as possibly build NGO support for such a WTO investment agreement.

\section{CONCLUSION}

The obstacles facing the successful conclusion of investment negotiations in the WTO seem formidable. Since the end of the Second World War, investment rules have largely been negotiated at the bilateral and regional levels, in part due to the perceived resistance of developing countries to the prospect of multilateral investment rules. However, the failure of the OECD MAI highlights the fallacy that it is somehow easier to forge deep levels of liberalization amongst developed countries.

There are two essential challenges that WTO members face in negotiating investment rules in the WTO. First, a WTO agreement must reflect the interests of developing countries. This will require negotiators to think creatively, especially in order to avoid a MAItype scenario of simply replicating the very strong investment liberalization and protection provisions of NAFTA Chapter 11. The options for negotiation should not be perceived as a zero-sum game, with either full liberalization of discriminatory regulation or full protectionism. Given the political sensitivity of many investment restrictions, a WTO agreement will most likely have to constitute a compromise with a mix of liberalization provisions whilst preserving a degree of freedom to impose developmental restrictions. The last Section of the Article has put forward a series of suggestions to be considered in implementing such a compromise, including the architecture of the agreement and its impact on pre- 
admission restrictions, coverage of the damaging use of investment incentives, and sensitivity to the use of some performance requirements by host states.

Second, the WTO negotiatiors need to address some of the jurisprudence that has developed out of the NAFTA Chapter 11 case law. This second challenge is possibly the more difficult one. Many of these cases seem to represent an extension of the coverage of NAFTA Chapter 11 beyond clearly discriminatory measures to encompass seemingly legitimate regulations with little adverse impact on foreign investors. In part, much of the case law derives from the broad scope of the investment protection provisions in NAFTA Chapter 11. The broad scope of these provisions seems somewhat anachronous in the current international environment where investors are more interested in gaining access and freedom to operate in host states. As such, the WTO negotiators should carefully consider the utility of overly strong and undefined investment protection provisions. A better approach would be to focus on granting protection from direct expropriation. However, by itself, this approach will not solve all of the problematic tendencies flowing from the NAFTA case law. The most difficult issue that WTO negotiators will need to address is the way in which a national treatment norm should apply in an investment context. The NAFTA experience and the MAI approach have followed the longstanding practice in BITs of importing the national treatment norm from GATT. However, little attention has been given to the potentially broad application of the concept of de facto discrimination in the investment context. It is essential that a WTO investment agreement manage the task of delineating the coverage of de facto discrimination in such a way as to preserve core components of regulatory autonomy. The suggestions put forward in the final Section of this Article are not intended to be exhaustive in this respect. They are, however, an invitation to examine this difficult issue further. 
